\title{
Anti-Virulence Properties of Plant Species: Correlation between In Vitro Activity and Efficacy in a Murine Model of Bacterial Infection
}

\author{
José Luis Díaz-Núñez ${ }^{1,+}$, Macrina Pérez-López ${ }^{1,+}{ }^{1}$, Norma Espinosa ${ }^{2}$, Nayelli Campos-Hernández ${ }^{1}$, \\ Rodolfo García-Contreras ${ }^{3}{ }^{\mathbb{D}}$, Miguel Díaz-Guerrero ${ }^{2}$, Humberto Cortes-López ${ }^{1}$, Monserrat Vázquez-Sánchez ${ }^{1}$, \\ Héctor Quezada ${ }^{4}$ (D), Mariano Martínez-Vázquez ${ }^{5}$ iD, Ramón Marcos Soto-Hernández ${ }^{1}$ (D), \\ Mireya Burgos-Hernández ${ }^{1}$, Bertha González-Pedrajo ${ }^{2, *} \mathbb{D}$ and Israel Castillo-Juárez ${ }^{1, *(D)}$
}

1 Laboratorio de Fitoquímica, Posgrado de Botánica, Colegio de Postgraduados, Texcoco 56230, Mexico; alucard_d_n@hotmail.com (J.L.D.-N.); maky1117@hotmail.com (M.P.-L.); camposh.nayelli@gmail.com (N.C.-H.); b_et_ocl@hotmail.com (H.C.-L.); vazquez.monserrat@colpos.mx (M.V.-S.); msoto@colpos.mx (R.M.S.-H.); burgos.mireya@colpos.mx (M.B.-H.)

2 Departamento de Genética Molecular, Instituto de Fisiología Celular, Universidad Nacional Autónoma de México, Ciudad de México 04510, Mexico; nespino@ifc.unam.mx (N.E.); madiaz@ifc.unam.mx (M.D.-G.)

check for updates

Citation: Díaz-Núñez, J.L.; Pérez-López, M.; Espinosa, N.; Campos-Hernández, N.;

García-Contreras, R.; Díaz-Guerrero, M.; Cortes-López, H.; Vázquez-Sánchez, M.; Quezada, H.; Martínez-Vázquez, M.; et al. Anti-Virulence Properties of Plant Species: Correlation between In Vitro Activity and Efficacy in a Murine Model of Bacterial Infection. Microorganisms 2021, 9, 2424. https://doi.org/10.3390/ microorganisms 9122424

Academic Editor: Ronit Sionov

Received: 2 October 2021

Accepted: 15 November 2021

Published: 25 November 2021

Publisher's Note: MDPI stays neutral with regard to jurisdictional claims in published maps and institutional affiliations.

Copyright: (c) 2021 by the authors. Licensee MDPI, Basel, Switzerland. This article is an open access article distributed under the terms and conditions of the Creative Commons Attribution (CC BY) license (https:/ / creativecommons.org/licenses/by/ $4.0 /)$.
3 Departamento de Microbiología y Parasitología, Facultad de Medicina, Universidad Nacional Autónoma de México, Ciudad de México 04510, Mexico; rgarc@bq.unam.mx

4 Laboratorio de Investigación en Inmunología y Proteómica, Hospital Infantil de México Federico Gómez, Ciudad de México 06720, Mexico; hquezadap@yahoo.com.mx

5 Departamento de Productos Naturales, Instituto de Química, Universidad Nacional Autónoma de México, Ciudad de México 04510, Mexico; marvaz@unam.mx

* Correspondence: bpedrajo@ifc.unam.mx (B.G.-P.); israel.castillo@colpos.mx (I.C.-J.); Tel.: +52-55-56225965 (B.G.-P.); +52-595-9520200 (ext. 1300) (I.C.-J.)

$+\quad$ These authors contributed equally.

\begin{abstract}
Several plant extracts exhibit anti-virulence properties due to the interruption of bacterial quorum sensing (QS). However, studies on their effects at the preclinical level are scarce. Here, we used a murine model of abscess/necrosis induced by Pseudomonas aeruginosa to evaluate the antipathogenic efficacy of 24 plant extracts at a sub-inhibitory concentration. We analyzed their ability to inhibit QS-regulated virulence factors such as swarming, pyocyanin production, and secretion of the ExoU toxin via the type III secretion system (T3SS). Five of the seven extracts with the best anti-pathogenic activity reduced ExoU secretion, and the extracts of Diphysa americana and Hibiscus sabdariffa were identified as the most active. Therefore, the abscess/necrosis model allows identification of plant extracts that have the capacity to reduce pathogenicity of P. aeruginosa. Furthermore, we evaluated the activity of the plant extracts on Chromobacterium violaceum. T3SS $(\triangle e s c U)$ and QS $(\Delta c v i I)$ mutant strains were assessed in both the abscess/necrosis and sepsis models. Only the $\Delta e s c U$ strain had lower pathogenicity in the animal models, although no activity of plant extracts was observed. These results demonstrate differences between the anti-virulence activity recorded in vitro and pathogenicity in vivo and between the roles of QS and T3S systems as virulence determinants.
\end{abstract}

Keywords: cutaneous infection model; type III secretion system; quorum sensing; Chromobacterium violaceum; Pseudomonas aeruginosa; Diphysa americana; Hibiscus sabdariffa

\section{Introduction}

Bacteria are social microorganisms that use quorum sensing (QS) to communicate and induce multicellular behaviors [1]. QS is dependent on cell density and is a mechanism by which bacteria release chemical signals (called autoinducers) to their microenvironment to perceive the presence of other cells [2]. This phenomenon allows bacteria to regulate expression of genes that control production of various metabolites and virulence factors, which is the reason it is considered an important target to block bacterial pathogenicity [3]. 
Thus far, plant species have positioned themselves as one of the primary sources of antivirulence substances, but one of the most significant challenges is to confirm their antipathogenic efficacy at the preclinical and clinical level [4-7].

Although there are reports of phytochemicals with anti-virulence properties that reduce the pathogenicity of Pseudomonas aeruginosa in some animal models (Caenorhabditis elegans, Danio rerio, and Galleria mellonella), in the case of murine models, the reports are scarce $[3,8]$. In P. aeruginosa, a reduction in pathogenicity due to QS inhibition has been reported in some mouse models, such as induced thermal injury, lung infection, and foreignbody infection [9-12]. Mainly, the reduction of pathogenicity of QS mutant strains relative to their parental strains [9-11] and the decreased virulence promoted by some molecules such as furanones $[13,14]$ have been demonstrated. In the case of phytochemicals, the prophylactic administration of synthetic ajoene $[(E, Z)-4,5,9$-trithiadodeca-1,6,11-triene 9 oxide] in the PAO1 lung infection model reduced bacterial load by 500 times in the lungs relative to untreated mice [14], while in the urinary tract infection model, oral administration of garlic significantly reduced bacterial load and prevented kidney damage [15].

Moreover, several screens have also been carried out using biosensor strains that contain a QS genetic circuit and an indicator gene, which produces pigments or fluorescence to facilitate quantification of QS inhibition [16]. In most studies evaluating anti-virulence activity with substances of plant origin, inhibition of pigment biosynthesis regulated by QS, such as violacein in Chromobacterium violaceum and pyocyanin in P. aeruginosa, has been commonly used [17-19]. To a lesser extent, other relevant targets such as type III secretion systems (T3SSs) [20,21], key enzymes [22], toxins [23], or two-component systems, among others, have also been evaluated [24-28].

P. aeruginosa is an opportunistic pathogen that causes nosocomial outbreaks that are difficult to control due to the presence of antibiotic-resistant strains [29,30]. Various regulatory mechanisms participate in its pathogenesis, e.g., three QS systems called LasI/LasR, RhlI/RhlR, and PQS [31]. QS controls the acquisition of iron through pyochelin and pyoverdine, the release of toxins such as phenazines and hydrogen cyanide, the production of pyocyanin, alginate, and lipopolysaccharides, as well as swarming and biofilm formation, among others [32]. Autoinducers of the diffusible signal factor (DSF) family also participate in this process through the PA1396 sensor kinase, which perceives DSFs released by other bacteria into the medium [33-35].

In addition, $P$. aeruginosa produces a DSF called cis-2-decenoic acid (CDA) that regulates swarming and pyoverdine production, induces biofilm dispersion, and promotes systemic infection in mice [36,37]. This bacterium also has a T3SS that translocates the effector proteins ExoY, ExoT, ExoS, and ExoU into host cells [38,39]. ExoU is a phospholipase A2 that causes host cell lysis and is the most toxic effector, thus it is recognized as a critical anti-virulence target [40].

C. violaceum is a saprophytic soil bacterium and an occasional opportunistic pathogen in humans [41]. It has a QS system called CviI/CviR, which consists of the CviI synthase and the cytoplasmic transcriptional regulator CviR [42]. This system regulates the synthesis of the pigment violacein and some virulence factors such as production of protease, chitinase, formation of biofilm, swarming [43], and the type VI secretion system [42,44,45]. Similarly, it has a T3SS located on the Cpi-1/-1a pathogenicity island, which is necessary for bacterial pathogenicity in a sepsis model in mice [46].

Among the challenges facing the development of anti-virulence therapies is verification of the beneficial effect at the preclinical and clinical levels [3,7]. Therefore, the purpose of our study was to evaluate the anti-pathogenic properties of 24 plant extracts at subinhibitory concentrations in murine infection models, and to analyze the participation of QS and T3SS. Although there is no consensus on the most suitable murine infection model to evaluate anti-virulence substances [8], it has been proposed that the abscess/necrosis model is reproducible with a small number of animals and allows infection by different bacterial species, including P. aeruginosa $[47,48]$. Using similar models, the identification of some anti-virulence triterpenes against Staphylococcus aureus has been reported [49-51]. 
Likewise, we have recently identified hibiscus acid isolated from Hibiscus sabdariffa as a compound with anti-pathogenic activity using the abscess/necrosis model [19].

In this work, we identify plant extracts that reduce the pathogenicity of P. aeruginosa at sub-inhibitory concentrations and others that stimulate it. However, of the two phenotypes evaluated in vitro (swarming and pyocyanin), only swarming inhibition correlated with anti-pathogenic activity in vivo. In addition, most of the extracts with better activity also reduced ExoU secretion.

Moreover, to the best of our knowledge, this is the first report to analyze the pathogenicity of a $\triangle c v i I(C V O 26)$ mutant in murine models. We showed that the Cvil synthase is not a pathogenicity determinant compared to the T3SS of this bacterium. Our results reveal substantial differences that must be considered when using these two bacterial species to identify anti-virulence substances and their usefulness for preclinical analysis.

\section{Materials and Methods}

\subsection{Plant Materials and Extract Preparation}

The plants were collected in Mexico, and the specimens were deposited in the Herbarium-Hortorio CHAPA of the Colegio de Postgraduados (Table S1). The plant material was dried at room temperature for one week, ground, and degreased with hexane $(1: 10, w / v)\left(\right.$ J.T. Baker ${ }^{\circledR}$, Belmont, NC, USA). After removing the solvent under reduced pressure (Buchi-R114, Flawil, Switzerland), the residues were macerated three times every $24 \mathrm{~h}$ with dichloromethane $(1: 10, w / v)$ (J.T. Baker ${ }^{\circledR}$, Belmont, NC, USA). Finally, the supernatant was filtered (filter paper, Whatman International Ltd., Maidstone, England) and the solvent was removed under reduced pressure (Buchi-R114, Flawil, Switzerland) and stored in dark flasks at $4{ }^{\circ} \mathrm{C}$ until use. For the evaluation of biological activity, the samples were dissolved in dimethyl sulfoxide (DMSO) (Sigma-Aldrich, St. Louis, MO, USA), and by growth curves or by plate count, it was determined that the concentrations used did not affect bacterial growth.

Quantitative Determination of Flavonoids and Triterpenoids

The extracts were diluted in methanol (HPLC, J.T. Baker ${ }^{\circledR}$, Belmont, NC, USA) at $0.25 \mathrm{mg} / \mathrm{mL}$. For quantification of flavonoids, the aluminum chloride colorimetric method (ACM) was used [52], while triterpenoids were determined by the reaction of vanillin and with perchloric acid [53] (Table S3). In the ACM, $0.5 \mathrm{~mL}$ of extract was added to the reaction mixture that contained $2.8 \mathrm{~mL}$ of distilled water, $1.5 \mathrm{~mL}$ of $95 \%$ ethanol, $0.1 \mathrm{~mL}$ of $1 \mathrm{M}$ potassium acetate, and $0.1 \mathrm{~mL}$ of $10 \%$ aluminum chloride. It was incubated at room temperature for $30 \mathrm{~min}$, and the absorbance at $415 \mathrm{~nm}$ was measured. To quantify the triterpenoids, $0.03 \mathrm{~mL}$ of the extract was dissolved in $0.1 \mathrm{~mL}$ of ethanol and concentrated in a water bath $\left(90^{\circ} \mathrm{C}\right)$. Subsequently, $0.4 \mathrm{~mL}$ of glacial acetic acid and $0.1 \mathrm{~mL} 5 \%$ vanillin were added. The solution was heated for $30 \mathrm{~min}$ at $60^{\circ} \mathrm{C}$ and cooled in an ice-water bath. Finally, $3 \mathrm{~mL}$ of glacial acetic acid was added, and the absorbance at $550 \mathrm{~nm}$ was measured. A calibration curve was used to calculate the concentrations of flavonoids and triterpenoids, and they were expressed in milligrams of quercetin or ursolic acid/g of extract (Table S3).

HPLC analysis of the D. americana extract was carried out on an Agilent 1260 Infinity equipped with an autosampler and a diode array detector (Agilent Technologies, Santa Clara, CA, USA). An ODS C18 column $\left(125 \times 4.6 \mathrm{~mm}, 5 \mu \mathrm{m}\right.$, Thermo Scientific ${ }^{\circledR}$, Hypersil $^{\circledR}$, Walthan, MA, USA) was used, and as mobile phase, an acetonitrile/water gradient ( $\mathrm{pH} 2.5)$ with a flow rate of $1 \mathrm{~mL} / \mathrm{min}$ at $30^{\circ} \mathrm{C}$ was used with a detection wavelength of $330 \mathrm{~nm}$.

\subsection{Bacterial Strains and Culture Conditions}

The P. aeruginosa PA14 wild-type (WT) strain and derived mutants $(\Delta l a s R / \Delta r h l R$ and $\Delta p s c C$ ) used in this study are listed in Table S2. In the case of $C$. violaceum, the ATCC $^{\circledR} 31532^{\mathrm{TM}}$ (The American Type Culture Collection, Manassas, VA, USA) WT and the mutant $\Delta c v i I$ (CV026, CDBB1423) strains were obtained from Colección Nacional de 
Cepas Microbianas y Cultivos Celulares, CINVESTAV (CINVESTAV-IPN, CDMX, Mexico) (Table S2).

\section{Construction of the C. violaceum Mutant Strain $\Delta e s c U$}

The $\Delta e s c U$ mutant strain was constructed by allelic exchange using the recombinant suicide plasmid pRE112. Briefly, the pRE112 plasmid containing $770 \mathrm{bp}$ of DNA upstream and $896 \mathrm{bp}$ of DNA downstream of the escU gene was conjugated from the E. coli SM10 $\lambda$ pir (ATCC ${ }^{\circledR} 87450$ TM, The American Type Culture Collection, Manassas, VA, USA) donor strain into the $C$. violaceum WT strain. Colonies from the first homologous recombination event were selected for chloramphenicol resistance $(15 \mu \mathrm{g} / \mathrm{mL})$ and for violacein production (purple colonies). The second event of recombination was selected on LB plates containing 5\% sucrose. Elimination of the escl gene from the chromosome was corroborated by PCR.

\subsection{Swarming Inhibition}

Swarming inhibition was determined as previously reported [54]. Three milliliters of M9 (0.6\% agar) was added per well with the different treatments in 6-well plates (Corning ${ }^{\circledR}$, Corning, NY, USA) and allowed to dry under sterile conditions for $45 \mathrm{~min}$. Subsequently, $25 \mu \mathrm{L}$ of an overnight culture of P. aeruginos $a$ was adjusted to an O.D. $600 \mathrm{~nm}=0.08$ and inoculated in the center of each well. The plates were incubated at $37^{\circ} \mathrm{C}$ for $24 \mathrm{~h}$ in a humid chamber (Thermo Scientific ${ }^{\circledR}$, Walthan, MA, USA), and the Image $J^{\circledR}$ program (Bethesda, $\mathrm{MD}, \mathrm{USA}$ ) was used to calculate the swarming area.

\subsection{Pyocyanin Production}

Pyocyanin was determined as previously reported [55]. Bacterial cultures (O.D.600 nm $=0.08$ ) were centrifuged at $4000 \times g$ for $3 \mathrm{~min}$, and $0.8 \mathrm{~mL}$ of supernatants was collected. The supernatants were vortexed with $0.42 \mathrm{~mL}$ of chloroform (J.T. Baker ${ }^{\circledR}$, Belmont, NC, USA) for $2 \mathrm{~min}$. The samples were centrifuged at $4000 \times g$ for $8 \mathrm{~min}$. The organic phase was collected and added to $0.8 \mathrm{~mL}$ of $0.2 \mathrm{~N} \mathrm{HCl}$. The samples were vigorously shaken for 1 min (vortex 2, IKA ${ }^{\circledR}$, Walthan, MA, USA). Then, $0.65 \mathrm{~mL}$ of the aqueous phase was taken, and $0.65 \mathrm{~mL}$ distilled water was added. Pyocyanin was determined at $520 \mathrm{~nm}$. The data were normalized to cell density.

\subsection{Type III Secretion Assay}

Overnight cultures of $P$. aeruginosa grown at $37^{\circ} \mathrm{C}$ and $250 \mathrm{rpm}$ in LB medium were used to inoculate (1:200) modified LB medium supplemented with $200 \mathrm{mM} \mathrm{NaCl}, 10 \mathrm{mM}$ $\mathrm{MgCl}_{2}, 0.5 \mathrm{mM} \mathrm{CaCl}$, and $5 \mathrm{mM}$ EGTA. The bacterial cultures were grown under the same conditions in the absence or presence of $200 \mu \mathrm{g} / \mathrm{mL}$ of the dichloromethane extracts, until reaching an O.D. $600 \mathrm{~nm}=0.8$. Phenoxyacetamide $25 \mu \mathrm{M}$ (MBX 1641) (ChemBridge, San Diego, CA, USA) was used as a positive control [48]. Each culture was centrifuged at $18,100 \times g$ for $2 \mathrm{~min}$ at $4{ }^{\circ} \mathrm{C}$. The supernatants were centrifuged once again and transferred to clean tubes. Secreted proteins were precipitated from the supernatant using $10 \%$ trichloroacetic acid (TCA) and centrifuged at $18,100 \times \mathrm{g}$ for $30 \mathrm{~min}$ at $4{ }^{\circ} \mathrm{C}$. The resulting bacterial and protein pellets were resuspended in Laemmli SDS loading buffer, which for the supernatant samples contained $10 \%$ saturated Tris to neutralize residual TCA. All samples were normalized according to each culture O.D. and separated on $15 \%$ polyacrylamide gels under denaturing conditions. Proteins were detected by Western blot analysis using anti-ExoU polyclonal antibodies and a chemiluminescent detection system (Merck-Millipore, Darmstadt, Germany). Western blot images were quantified densitometrically using the Image Studio Lite software (LI-COR, Lincoln, NE, USA).

\subsection{Virulence Factors Regulated by QS in C. violaceum}

Overnight cultures of $C$. violaceum $31532 \mathrm{WT}$ and $\Delta e s c U$ and $\Delta c$ coil mutant strains were adjusted to an O.D.660 nm $=0.1$ (Spectronic ${ }^{\circledR}$ Genesys $^{\mathrm{TM}}$ 5, Texas city, TX, USA) and incu- 
bated in multiwell plates (Corning ${ }^{\circledR}$, Corning, NY, USA) for $18 \mathrm{~h}$. The supernatants were obtained by centrifugation at $4000 \times g$ for $3 \mathrm{~min}$ and were used to determine proteolytic, hemolytic, and chitinolytic activity. The plates were incubated for $48 \mathrm{~h}$ at $28{ }^{\circ} \mathrm{C}$, and a digital caliper (STEREN ${ }^{\circledR}$, CDMX, Mexico) was used to measure the areas of activity.

\subsubsection{Proteolytic, Hemolytic, and Chitinolytic Activity}

The evaluation was carried out as previously reported. For the case of hemolytic and protease activity, ten microliters of supernatant was added to the wells previously prepared on 5\% sheep blood agar plates and milk agar plates, respectively [56]. For the case of chitinase activity, it was added to wells in M9 medium plates (Difco Laboratories, Detroit, MI, USA) with $2 \%$ colloidal chitin (Sigma-Aldrich, St. Louis, MO, USA) [57].

\subsubsection{Biofilm Formation}

Overnight cultures were adjusted to an O.D. $660 \mathrm{~nm}=0.1$, transferred to glass tubes, and incubated for $48 \mathrm{~h}$ at $28^{\circ} \mathrm{C}$ [43]. Subsequently, the tubes were washed with distilled water and dried at $40{ }^{\circ} \mathrm{C}$. After adding $1 \mathrm{~mL}$ of $0.1 \%$ crystal violet and incubating for $20 \mathrm{~min}$, this same procedure was carried out. Finally, the crystal violet was solubilized with $1 \mathrm{~mL}$ of $80 \%$ ethanol, and the absorbance at $570 \mathrm{~nm}$ was measured. The data were normalized with bacterial growth at $660 \mathrm{~nm}$.

\subsubsection{Swarming Motility}

Overnight cultures were adjusted to an O.D. $660 \mathrm{~nm}=0.05$, and $2 \mu \mathrm{L}$ of inoculum was placed in the center of the semisolid plate $(0.25 \%$ agar) [58], which was incubated for $24 \mathrm{~h}$ in a moist chamber at $28^{\circ} \mathrm{C}$ (Thermo Scientific ${ }^{\circledR}$, Walthan, MA, USA), and the displacement area was measured.

\subsection{Animal Studies}

Six- to eight-week-old CD-1 mice (equal ratio of males and females) were obtained from the Facultad de Estudios Superiores, Cuautitlán-UNAM. The animals were kept under standard conditions $\left(23^{\circ} \mathrm{C} \pm 2{ }^{\circ} \mathrm{C}\right)$ with a $12 \mathrm{~h} \mathrm{light-dark}$ cycle and free access to food (Lab rodent diet 5001, LabDiet ${ }^{\circledR}$, Saint Louis, MO, USA) and water.

\subsubsection{Abscess/Necrosis Model with P. aeruginosa}

Overnight cultures $\left(37^{\circ} \mathrm{C}\right)$ were adjusted to an O.D. $600 \mathrm{~nm}=0.06$, incubated until reaching an O.D. $600 \mathrm{~nm}=1-1.5$ and adjusted to a final absorbance of 0.08 (Spectronic ${ }^{\circledR}$ Genesys $^{\mathrm{TM}} 5$, Texas city, TX, USA). The cultures were centrifuged at $4000 \times g$ for $5 \mathrm{~min}$, and the bacterial pellets were washed with PBS (three times) to obtain $60 \mu \mathrm{L}$ of inoculum containing $10^{7} \mathrm{CFU}$ of P. aeruginosa. The inoculum was mixed with the plant extracts, and bacterial viability was determined by plate count. Additionally, to determine the toxicity of some extracts, they were injected without bacteria into the animals (Figure S9). Inoculation was carried out following a procedure reported elsewhere [47,48]. Mice were anesthetized with $64 \mathrm{mg} / \mathrm{kg}$ sodium pentobarbital (Pisabental, $\mathrm{PiSa}^{\circledR}$ Agropecuaria, Hidalgo, Mexico) and the right thigh depilated with an electric razor and chemical depilator (RemoveLoquay ${ }^{\circledR}$, CDMX, Mexico). One day later, the animals were re-anesthetized and injected subcutaneously with $60 \mu \mathrm{L}$ of the inoculum.

The abscess area was measured at $24 \mathrm{~h}$ and the area of necrosis at $48 \mathrm{~h}$ with a digital caliper (STEREN ${ }^{\circledR}$, CDMX, Mexico). On the fourth day, the animals were anesthetized and sacrificed by cervical dislocation. Lesions and livers were removed to calculate CFU/g of tissue by plate count.

\subsubsection{Sepsis and Abscess/Necrosis Model with C. violaceum}

The bacterial inoculum was prepared from overnight cultures incubated at $28^{\circ} \mathrm{C}$ and adjusted to an O.D.600 nm $=0.5$ (Spectronic ${ }^{\circledR}$ Genesys $^{\text {TM }}$ 5, Texas City, TX, USA). The cultures were centrifuged at $4000 \times g$ for $5 \mathrm{~min}$, and the bacterial pellets were washed with 
PBS (three times) to obtain the final inoculum of $10^{9} \mathrm{CFU} / 0.2 \mathrm{~mL}$. The sepsis model was based on a previous report [46], and the animals were inoculated intraperitoneally with $3 \times 10^{9} \mathrm{CFU} / 0.2 \mathrm{~mL}$.

In the abscess/necrosis model, the same procedure as with P. aeruginosa was followed, with the difference that $60 \mu \mathrm{L}\left(1.5 \times 10^{9} \mathrm{CFU}\right)$ was inoculated into the right thigh of the animal, and the necrotic areas were measured up to $96 \mathrm{~h}$.

In animal model assays, the incubation time of the inoculum with the plant extracts was approximately $20 \mathrm{~min}$, at room temperature and without shaking. Subsequently, the viability of the inoculum was determined by the plate count method.

\subsection{Statistical Analysis}

The different parametric and non-parametric statistics used are indicated in detail in the figure captions. The experimental data were analyzed with SigmaPlot version 14.0 (Systat Software GmbH, Erkrath, Germany), and the multivariate statistical analysis was performed with R statistical software package (version 3.6.0; https: / / www.r-project.org/ accessed on 28 September 2021). The Kaplan-Meier curve was performed with GraphPad Prisma 6 (GraphPad, San Diego, CA, USA) and the data analysis in the SPSS 22.0 program (IBM Corporation, New York, NY, USA).

\subsection{Ethical Declaration}

All experiments with mice were carried out following the indications of the Research, Ethics and Biosafety Committees of the Hospital Infantil de México-Federico Gómez (HIM2018-002).

\section{Results}

\subsection{Effect of Plant Extracts on the Pathogenicity of P. aeruginosa}

The effect of 24 plant extracts (Table 1) at a sub-inhibitory concentration of $500 \mu \mathrm{g} / \mathrm{mL}$ (Figure S1) on the pathogenicity of P. aeruginosa was evaluated (Table 2, Figure S2). Subcutaneous inoculation of the PA14 WT strain induced the death of $42 \%$ (58\% survival) of the animals, an abscess area of $255.8 \mathrm{~mm}^{2}$ at $24 \mathrm{~h}$, and a necrotic area of $21.7 \mathrm{~mm}^{2}$ at $48 \mathrm{~h}$. Additionally, at $96 \mathrm{~h}$, establishment in the inoculation area was $\log _{10} 10.4 \mathrm{CFU} / \mathrm{g}$ and the systemic dispersion of $\log _{10} 3.2 \mathrm{CFU} / \mathrm{g}$ in the liver (Table 2). Interruption of the QS $(\Delta l a s R / \Delta r h l R)$ and T3SS $(\Delta p s c C)$ systems increased the survival of the mice to $100 \%$ and reduced the pathogenicity of the bacteria, with the effect being more evident with the $\triangle p s c C$ strain, which was not able to establish and generate damage (Table 2, Figure 1).

Table 1. Plant species used in this study.

\begin{tabular}{|c|c|c|c|c|}
\hline Species Name (Family) & Local Name & Folk Usage & Plant Part Extracted & Voucher \# \\
\hline $\begin{array}{c}\text { Allium glandulosum Link \& Otto } \\
\text { (Amaryllidacae) }\end{array}$ & Cebolla de monte & Edible & $\begin{array}{c}\text { Bulbs and } \\
\text { Leaves/flowers }\end{array}$ & 155,009 \\
\hline $\begin{array}{l}\text { Annona cherimola Mill. } \\
\text { (Annonaceae) }\end{array}$ & Chirimoya & $\begin{array}{l}\text { Edible, insecticide, and } \\
\text { medicinal }\end{array}$ & Leaves & 155,006 \\
\hline $\begin{array}{c}\text { Argemone platyceras Link \& Otto } \\
\text { (Papaveraceae) }\end{array}$ & $\begin{array}{l}\text { Chicalote, amapola } \\
\text { silvestre, cardo santo }\end{array}$ & $\begin{array}{l}\text { Medicinal and } \\
\text { ornamental }\end{array}$ & Whole plant & 155,007 \\
\hline Artemisa ludoviciana (Asteraceae) & Hierba maestra & Medicinal & Whole plant & 155,015 \\
\hline $\begin{array}{l}\text { Buddleja parviflora H.B. \& K } \\
\text { (Scrophulariaceae) }\end{array}$ & Tepozán & Medicinal & Whole plant & 155,014 \\
\hline $\begin{array}{c}\text { Diphysa americana (Mill.) M. } \\
\text { Sousa (Fabaceae) }\end{array}$ & Quebrache & Edible & Pods & 154,998 \\
\hline
\end{tabular}


Table 1. Cont.

\begin{tabular}{|c|c|c|c|c|}
\hline Species Name (Family) & Local Name & Folk Usage & Plant Part Extracted & Voucher \# \\
\hline $\begin{array}{c}\text { Euphorbia pulcherrima Willd. ex } \\
\text { Klotzsch (Euphorbiacea) }\end{array}$ & Flor de nochebuena & $\begin{array}{l}\text { Medicinal and } \\
\text { ornamental }\end{array}$ & Leaves & 155,008 \\
\hline $\begin{array}{c}\text { Gnaphalium viscosum Kunth } \\
\text { (Asteraceae) }\end{array}$ & Gordolobo & Medicinal & Whole plant & 155,013 \\
\hline $\begin{array}{l}\text { Gymnosperma glutinosum } \\
\text { (Spreng.) Less. (Asteraceae) }\end{array}$ & Tatalencho & Medicinal & Whole plant & 155,018 \\
\hline Hibiscus sabdariffa L. (Malvaceae) & Jamaica & Edible & Calyxes & $*$ \\
\hline $\begin{array}{l}\text { Ipomoea dumosa (Benth.) L.O. } \\
\text { Williams (Convolvulaceae) }\end{array}$ & Soyo & Edible & Leaves & 154,993 \\
\hline $\begin{array}{c}\text { Jaltomata procumbens (Cav.) J.L. } \\
\text { Gentry (Solanaceae) }\end{array}$ & Jaltomate & Edible & Fruits & 155,004 \\
\hline $\begin{array}{l}\text { Loeselia mexicana (Lam.) Brand } \\
\text { (Polemoniaceae) }\end{array}$ & Espinosilla & Medicinal & Whole plant & 155,012 \\
\hline $\begin{array}{l}\text { Metastelma angustifolium Turcz } \\
\text { (Apocynaceae) }\end{array}$ & Not available & Medicinal & Whole plant & 155,017 \\
\hline $\begin{array}{c}\text { Peperomia peltilimba C.DC. ex Trel. } \\
\text { aff. Peperomia aggravescens Trel. } \\
\text { (Piperaceae) }\end{array}$ & Tequelite & Edible & Edible & 154,994 \\
\hline Phaseolus coccineus L. (Fabaceae) & Frijol ayocote & Edible & Flowers & 154,992 \\
\hline Psidium guajava L. (Myrtaceae) & Guayaba & Edible & Whole plant & Not available \\
\hline Rumex crispus L. (Polygonaceae) & Quelite agrio & Edible & Leaves & 154,996 \\
\hline $\begin{array}{l}\text { Saurauia scabrida Hemsl. } \\
\text { (Actinidiaceae) }\end{array}$ & Acalama & Edible & Fruits & 155,002 \\
\hline $\begin{array}{l}\text { Smilax regelii Killip \& C.V. } \\
\text { Morton (Smilacaceae) }\end{array}$ & Cocolmeca & Edible & Stems & 154,999 \\
\hline Tagetes lucida Cav. (Asteraceae) & Pericón & Medicinal and edible & Whole plant & 155,016 \\
\hline $\begin{array}{l}\text { Tagetes micrantha Cav. } \\
\text { (Asteraceae) }\end{array}$ & Anicillo & Medicinal and edible & Whole plant & 155,011 \\
\hline $\begin{array}{c}\text { Xanthosoma sagittifolium (L.) } \\
\text { Schott (Araceae) }\end{array}$ & Quelite de lampazo & Edible & Leaves & 155,005 \\
\hline
\end{tabular}

* Previous study [19]. \# number.

Table 2. Effect of plant extracts at sub-inhibitory concentration on the pathogenicity of P. aeruginosa.

\begin{tabular}{|c|c|c|c|c|c|}
\hline \multirow{2}{*}{ Treatments } & \multirow{2}{*}{ Survival (\%) } & \multirow{2}{*}{$\begin{array}{c}\text { Abscess Area } \\
\left(\mathrm{mm}^{2}, \text { Mean } \pm \text { S.E. }\right)\end{array}$} & \multirow{2}{*}{$\begin{array}{c}\text { Necrotic Area } \\
\left(\mathrm{mm}^{2}, \text { Mean } \pm \text { S.E. }\right)\end{array}$} & \multirow{2}{*}{$\begin{array}{c}\text { Bacterial Load } \\
\text { Inoculation Area }\end{array}$} & \multirow{2}{*}{$\frac{\left(\log _{10} \text { CFU/g) }\right.}{\text { Liver }}$} \\
\hline & & & & & \\
\hline PA14 WT & 58 & $255.8 \pm 26.9$ & $21.7 \pm 3.7$ & $10.4 \pm 0.08$ & $3.2 \pm 0.05$ \\
\hline$\Delta l a s R / \Delta r h l R$ & 100 & $56.4 \pm 44.9^{*}$ & $6.2 \pm 2.4^{*}$ & $6.6 \pm 2.2 *$ & $0.7 \pm 0.7$ * \\
\hline$\Delta p s c C$ & 100 & $0 *$ & 0 * & 0 * & 0 * \\
\hline \multicolumn{6}{|c|}{ PA14 WT + plant extract $(500 \mu \mathrm{g} / \mathrm{mL})$} \\
\hline D. americana & 100 & $66.0 \pm 48.3^{*}$ & $1.6 \pm 0.2 *$ & $0 *$ & $0 *$ \\
\hline H. sabdariffa & 100 & $130.1 \pm 53.0$ & $7.5 \pm 3.6^{*}$ & $8.5 \pm 0.9 *$ & $0 *$ \\
\hline J. procumbens & 100 & $64.1 \pm 40.0^{*}$ & $5.9 \pm 3.7 *$ & $9.9 \pm 0.4$ & $2.9 \pm 0.08$ \\
\hline P. coccineus & 100 & $131.0 \pm 24.8$ & $15.8 \pm 5.4$ & $9.1 \pm 0.3$ & 0 * \\
\hline T. lucida & 100 & $146.0 \pm 13.5$ & $19.3 \pm 1.1$ & $9.1 \pm 0.9$ & $0 *$ \\
\hline L. mexicana & 100 & $124.0 \pm 14.4$ & $21.4 \pm 8.3$ & $9.9 \pm 0.3$ & $2.0 \pm 1.0$ \\
\hline P. peltilimba & 100 & $55.8 \pm 28.6^{*}$ & $41.8 \pm 28.0$ * & $6.9 \pm 3.5$ & $3.1 \pm 0.7$ \\
\hline
\end{tabular}


Table 2. Cont.

\begin{tabular}{|c|c|c|c|c|c|}
\hline \multirow{2}{*}{ Treatments } & \multirow{2}{*}{ Survival (\%) } & \multirow{2}{*}{$\begin{array}{c}\text { Abscess Area } \\
\left(\mathrm{mm}^{2}, \text { Mean } \pm \text { S.E. }\right)\end{array}$} & \multirow{2}{*}{$\begin{array}{c}\text { Necrotic Area } \\
\left(\mathrm{mm}^{2}, \text { Mean } \pm \text { S.E. }\right)\end{array}$} & Bacterial Load & \multirow{2}{*}{$\frac{\left(\log _{10} \mathrm{CFU} / \mathrm{g}\right)}{\text { Liver }}$} \\
\hline & & & & Inoculation Area & \\
\hline S. regelii & 66 & $53.5 \pm 30.5^{*}$ & $13.0 \pm 6.5$ & $5.7 \pm 2.9 *$ & $2.9 \pm 1.0$ \\
\hline G. viscosum & 66 & $158.3 \pm 80.4$ & $16.0 \pm 13.1$ & $7.8 \pm 0.5^{*}$ & 0 * \\
\hline B. parviflora & 66 & $107.2 \pm 32.0 *$ & $14.3 \pm 2.5$ & $10.1 \pm 0.2$ & 0 * \\
\hline P. guajava & 66 & $151.4 \pm 71.2$ & $19.9 \pm 5.5$ & $9.8 \pm 0.08$ & 0 * \\
\hline A. glandulosum-B & 66 & $212.5 \pm 68.8$ & $9.9 \pm 6.9$ & $10.2 \pm 0.02$ & $2.9 \pm 0.7$ \\
\hline A. cherimola & 66 & $168.4 \pm 1.6$ & $51.4 \pm 29.4^{*}$ & $10.2 \pm 0.1$ & $3.2 \pm 0.2$ \\
\hline T. micrantha & 33 & $172.5 \pm 38.4$ & $10.2^{\#}$ & $7.8^{\#}$ & $0^{\#}$ \\
\hline M. angustifolium & 33 & $218.4 \pm 45.4$ & $10.8^{\#}$ & $10.2^{\#}$ & $2.9^{\#}$ \\
\hline A. platyceras & 33 & $208.0 \pm 36.8$ & $12.8^{\#}$ & $10.3^{\#}$ & $3.6^{\#}$ \\
\hline E. pulcherrima & 33 & $192.7 \pm 96.4$ & $15.4 \pm 15.4$ & $8.9^{\#}$ & $3.4^{\#}$ \\
\hline S. scabrida & 33 & $149.2 \pm 41.6$ & $24.5^{\#}$ & $9.9^{\#}$ & $3.3^{\#}$ \\
\hline G. glutinosum & 33 & $227.5 \pm 8.7$ & $33.9^{\#}$ & $10.4^{\#}$ & $3.2^{\#}$ \\
\hline X. sagittifolium & 33 & $190.7 \pm 22.4$ & $40.3 \pm 14.5^{*}$ & $10.2^{\#}$ & $2.8^{\#}$ \\
\hline R. crispus & 0 & $310.9 \pm 28.6$ & $0^{\#}$ & - & - \\
\hline I. dumosa & 0 & $252.1 \pm 11.8$ & $21.1^{\#}$ & - & - \\
\hline A. glandulosum-L/F & 0 & $237.5 \pm 31.5$ & - & - & - \\
\hline A. ludoviciana & 0 & $176.9 \pm 21.1$ & $0^{\#}$ & - & - \\
\hline
\end{tabular}

The animals were inoculated subcutaneously with $10^{7} \mathrm{CFU}$ of the different strains. By counting standard plates, the viability of PA14 WT was determined after incubating them for $20 \mathrm{~min}$ at room temperature with the plant extracts. The area of the abscess was quantified $24 \mathrm{~h}$ after inoculation and the formation of necrosis at $48 \mathrm{~h}$, which corresponds to the maximum time of its formation. The animals were sacrificed at $96 \mathrm{~h}$, and the survival percentage and the CFU in the tissues were determined. The experiment was carried out once with groups of three animals per treatment, except the control groups with PA14 WT, which were two independent tests with three and four animals (Figure S2). * Significant difference from wild type ( $p \leq 0.05$; Kruskal-Wallis and $\alpha \leq 0.05$; Student-Newman-Keuls test). ${ }^{\#}$ Data are from a single animal so no statistical analysis could be performed. B: bulb; and L/F: leaves and flowers. - no data.

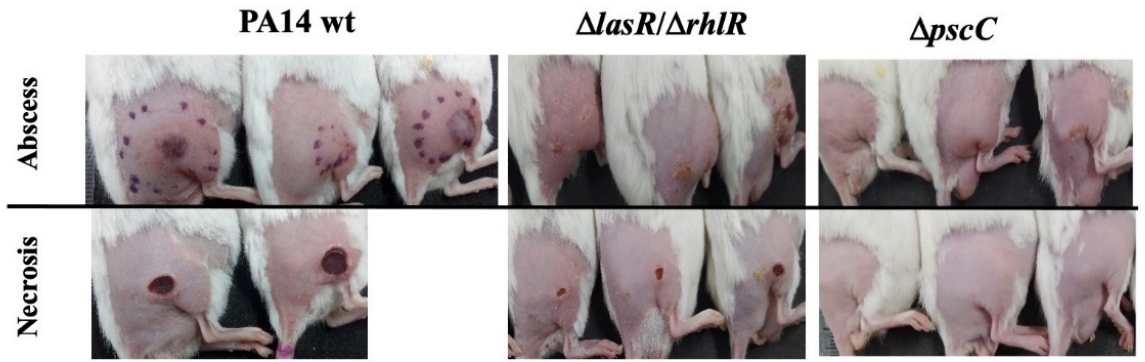

D. americana

H. sabdariffa

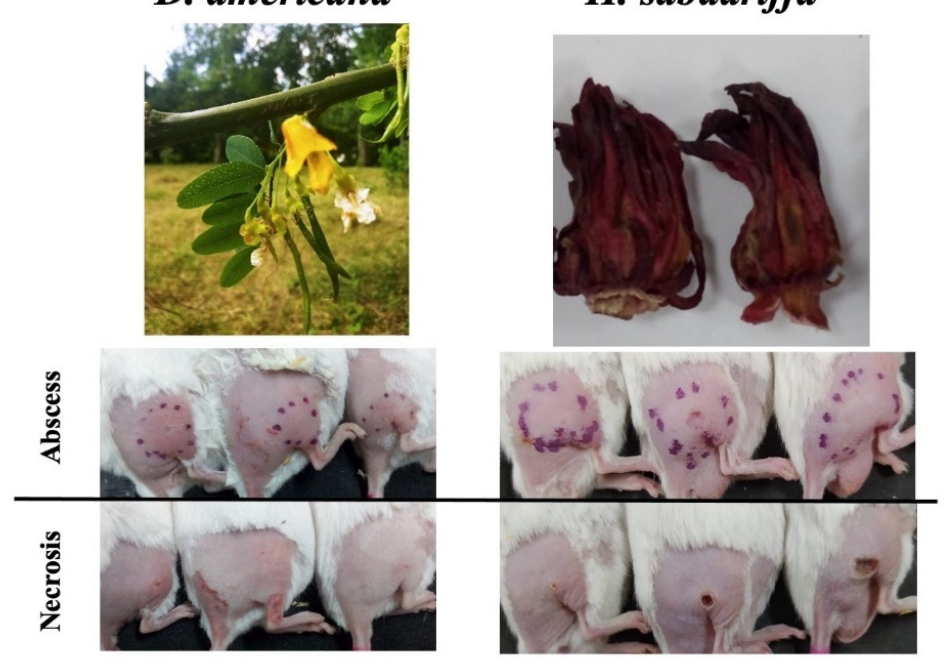

Figure 1. Representative images of the effect of mutations in QS $(\Delta l a s R / \Delta r h l R)$ and T3SS $(\Delta p s c C)$ of $P$. aeruginosa and the anti-pathogenic activity of dichloromethane extracts of $D$. americana (pods) and H. sabdariffa (calyxes) at a sub-inhibitory concentration of $500 \mu \mathrm{g} / \mathrm{mL}$. 
In the groups treated with the plant species, seven extracts $(29 \%)$ increased the survival of the infected animals to $100 \%$, highlighting D. americana and H. sabdariffa that also significantly reduced damage, establishment, and spread to the liver (Table 2, Figures 1 and S3). J. procumbens significantly reduced damage but did not prevent establishment and spread to the liver (Table 2), while P. coccineus and T. lucida only increased survival and prevented dispersal to the liver (Table 2). In the case of L. mexicana and P. peltilimba, although they increased the survival of the animals, they did not reduce the establishment of the bacteria or the damage, and with $P$. peltilimba, a larger necrotic area of $44.8 \mathrm{~mm}^{2}$ was recorded (Table 2). Finally, six extracts allowed $66 \%$ survival, but only G. viscosum, B. parviflora, and P. guajava prevented the systemic dispersal of the bacteria (Table 2).

Interestingly, 11 extracts (45\%) increased animal mortality relative to the group treated with PA14 WT. In seven treatments, a 33\% survival was recorded, where X. sagittifolium increased the necrotic area by $40.3 \mathrm{~mm}^{2}(\alpha<0.05)$ (Table 2$)$, while in the groups treated with R. crispus, I. dumosa, A. glandulosum-L/F, and A. ludoviciana, survival was 0\% (Table 2, Figure S3).

\subsubsection{Effect of Plant Extracts on Virulence Factors Regulated by QS in P. aeruginosa}

In the $\Delta l a s R / \Delta r h l R$ strain, pyocyanin production was reduced by $90 \%$, while in the PA14 WT group treated with the positive control C-30 furanone, reduction was 50\% (Figure 2A). In the case of the seven plant extracts that maintained 100\% survival of the animals (Table 2), six (P. peltilimba, P. coccineus, L. mexicana, J. procumbens, D. americana, and T. lucida) were correlated with a decrease of up to $54 \%$ in pyocyanin production $\left(\alpha \leq 0.05^{*}\right)$ (Figure 2A). H. sabdariffa stimulated pigment production by $14 \%\left(\alpha \leq 0.05^{*}\right.$ ) (Figure $2 \mathrm{~A}$ ). Interestingly, R. crispus, I. dumosa, A. glandulosum-L/F, and A. ludoviciana, which induced death in $100 \%$ of the animals, inhibited pyocyanin production by 17 to $48 \%\left(\alpha \leq 0.05^{*}\right)$ (Figure 2A). As expected, swarming was reduced by $92.6 \%$ in the $\Delta l a s R / \Delta r h l R$ strain and by $91.3 \%$ in the PA14 WT group treated with C-30 furanone (Figure 2B), while $91 \%$ of the extracts at $500 \mu \mathrm{g} / \mathrm{mL}$ strongly reduced swarming and only G. glutinosum and S. scabrida stimulated it from 10 to $35 \%$ at 125 and $250 \mu \mathrm{g} / \mathrm{mL}(\alpha \leq 0.05)$ (Figures $2 \mathrm{~B}$ and S4).

To determine the correlation between the variables involved in the effect of the extracts on pathogenicity, a principal component analysis (PCA) was carried out, and two groupings of different classes were identified. In the first place, the extracts with anti-pathogenic activity were related to increased survival and reduced necrosis, swarming, dissemination to the liver, and establishment of the bacteria in the inoculation area (Figure 3). Interestingly, as shown in principal component 2, the inhibition of pyocyanin does not reduce pathogenicity since it is the only variable that is not correlated (Figure 3). On the other hand, abscess formation correlated negatively with survival, which indicates it is a variable related to the increase in mortality and is placed where the second grouping of eight extracts is distributed (Figure 3). Finally, we identified five extracts whose behavior is not explained by the analyzed variables (Figure 3). 


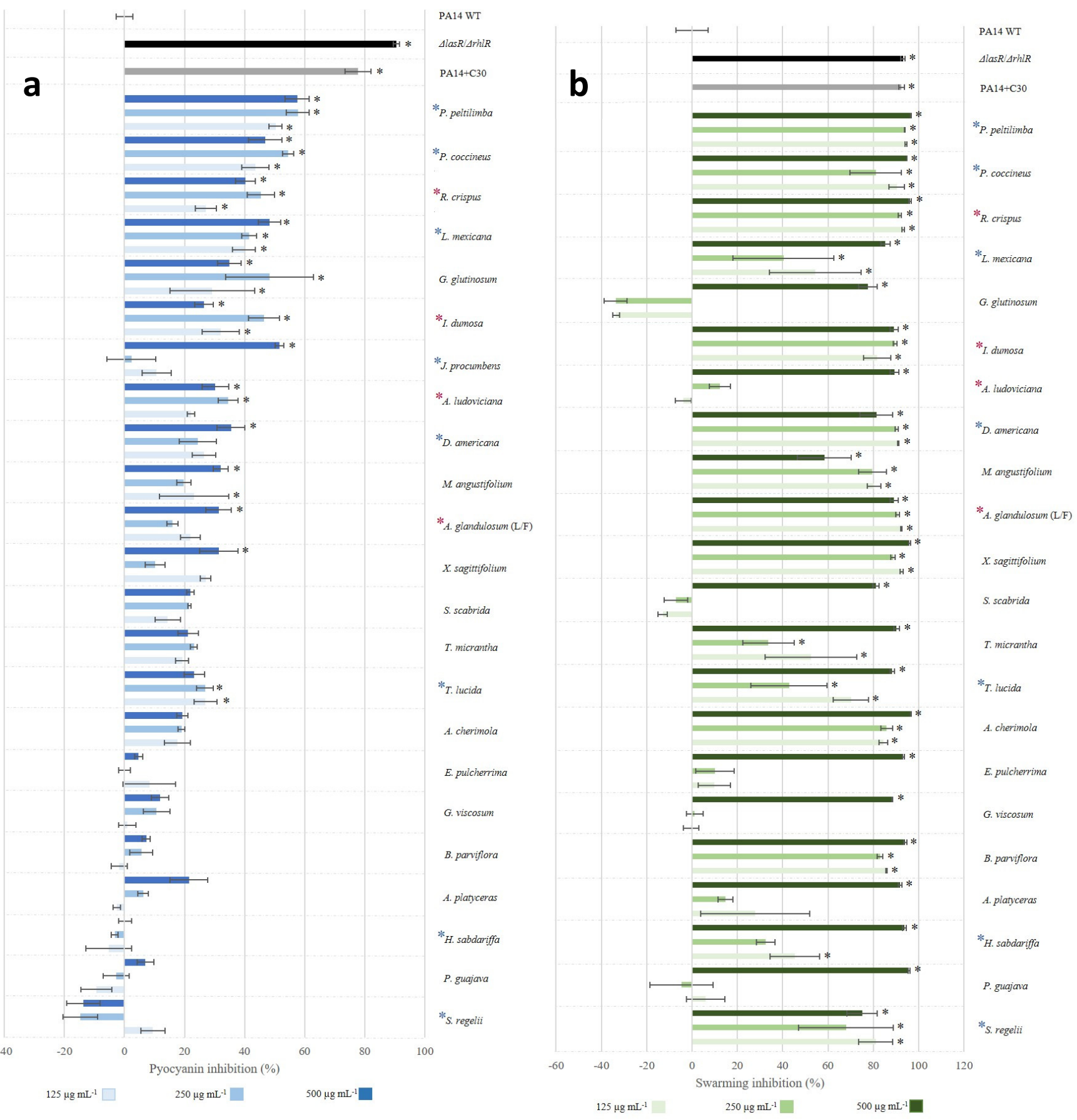

Figure 2. Anti-virulence activity of dichloromethane extracts on P. aeruginosa. (a) Pyocyanin inhibition and (b) swarming. The data represent the mean and the standard deviations of two repetitions with $n=5$. Significant difference from the wild type (Kruskal-Wallis, $p \leq 0.05^{*}$, and Student-Newman-Keuls test, $\alpha \leq 0.05 *$ ). C-30, furanone C30 (50 $\left.\mu \mathrm{M}\right)$. Blue asterisks indicate the main extracts that reduced pathogenicity and red asterisks indicate extracts that stimulated it in the animal model. 


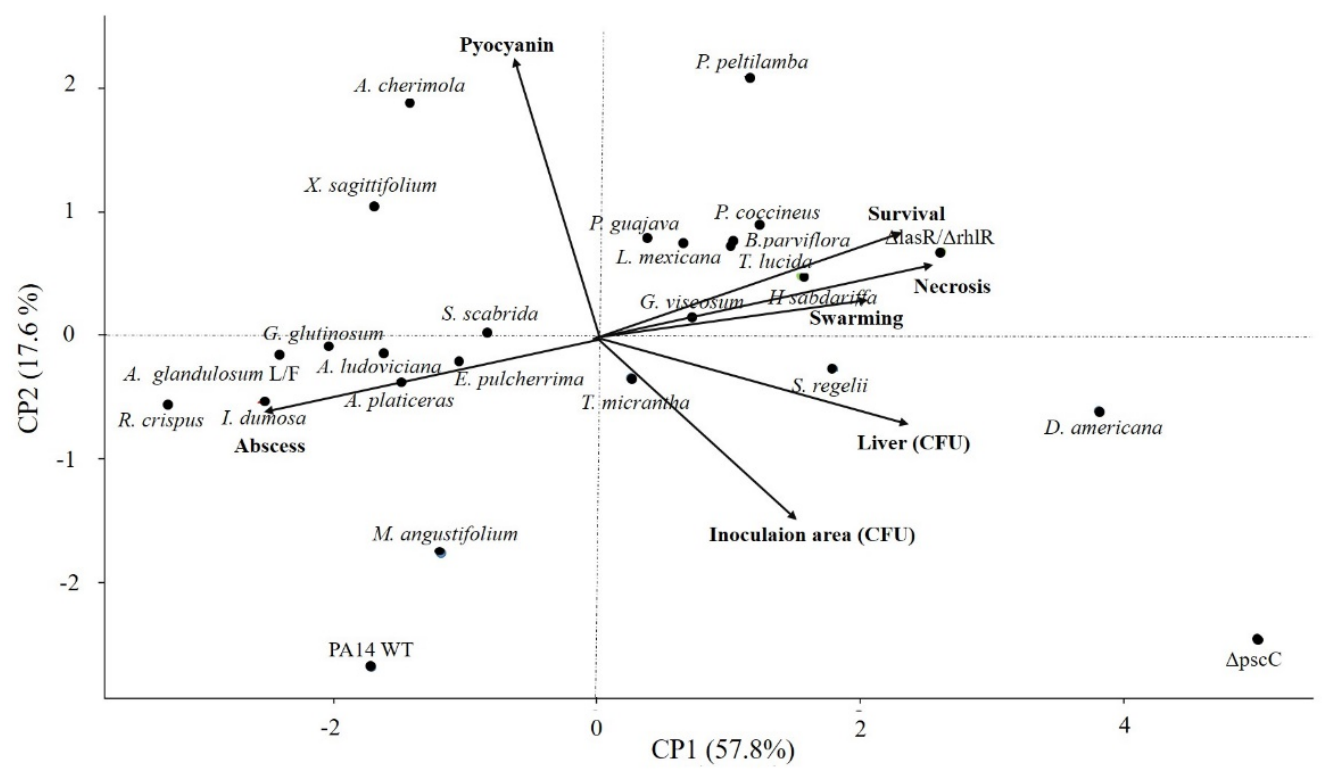

Figure 3. Principal component analysis of anti-virulence activity (in vitro) and anti-pathogenic capacity (abscess/necrosis model) of plant extracts in P. aeruginosa. The groups of extracts that reduce pathogenicity and those that stimulate it are shown. Mutant strains are also represented, in which the variance dispersion of the $\Delta l a s R / \Delta r h l R$ is more like the group of extracts with anti-pathogenic activity. The values were transformed into percentages, and the variables were managed under the inhibition premise, except for survival.

\subsubsection{Effect of Plant Extracts on T3SS of P. aeruginosa}

We analyzed the effect of seven plant extracts that reduced pathogenicity in the animal model (as well as $R$. crispus that stimulated it) on ExoU secretion (Figure 4a).

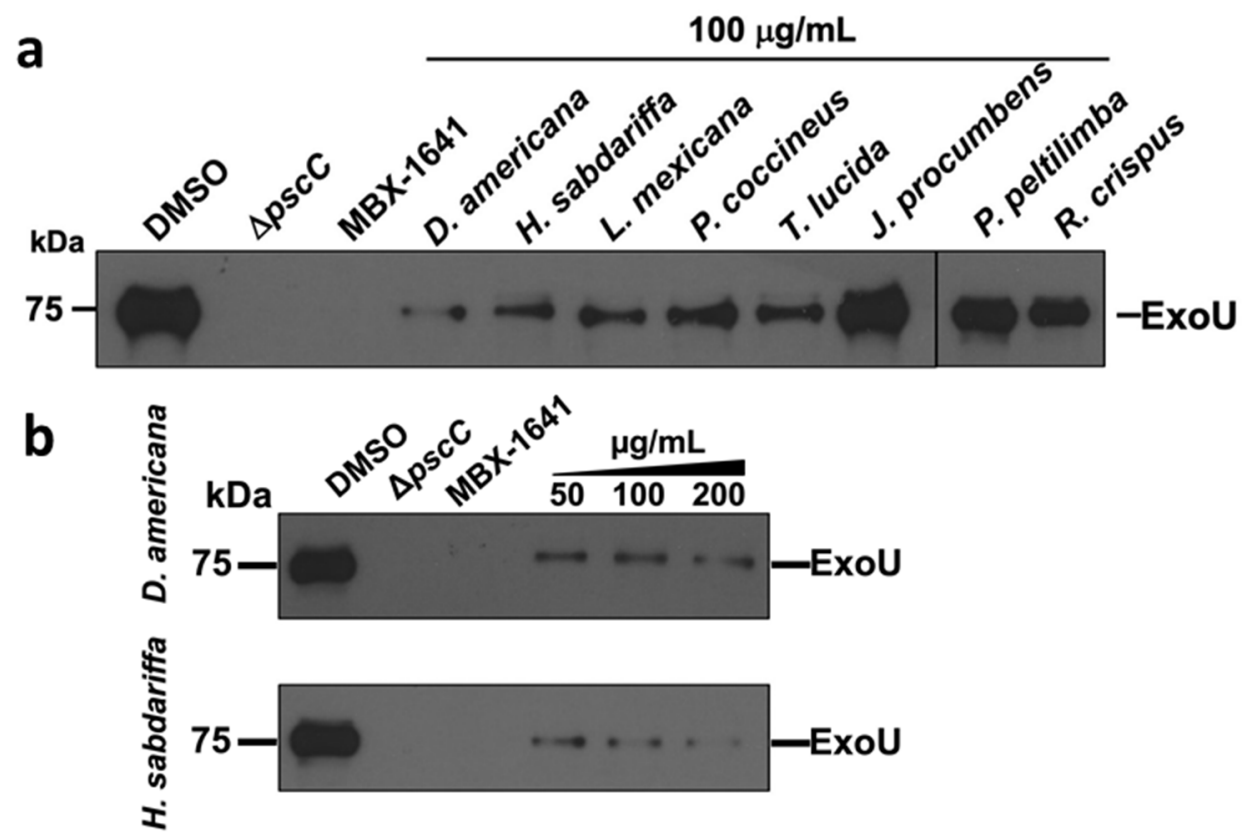

Figure 4. Cont. 


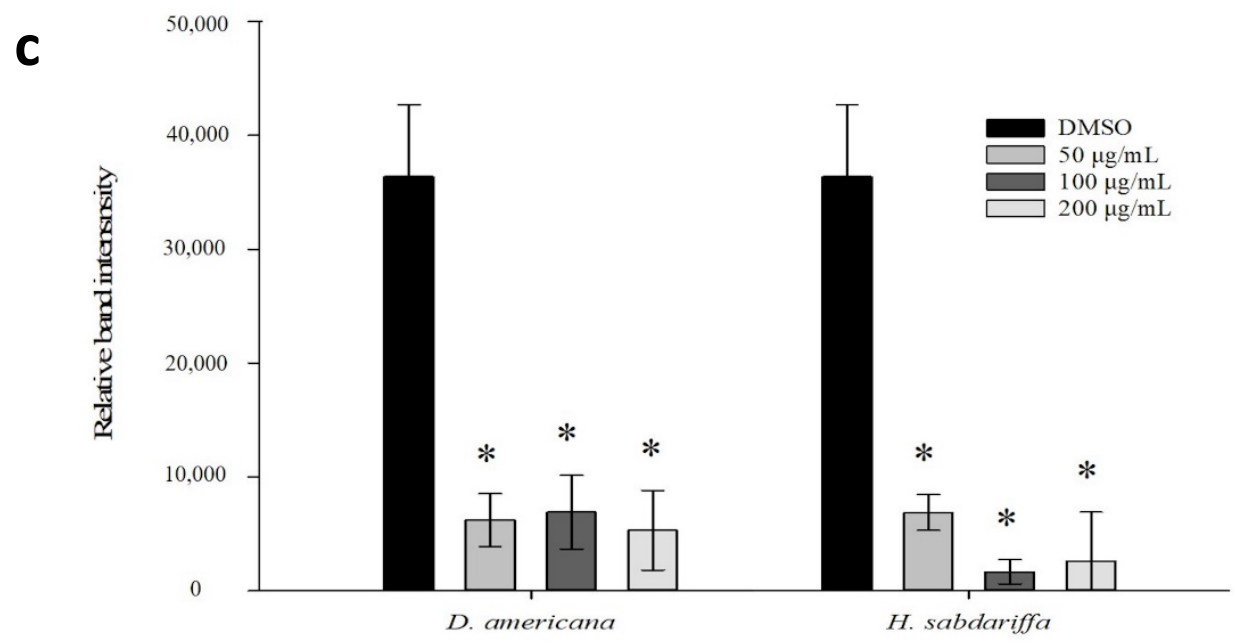

Figure 4. Effect of plant extracts on ExoU protein secretion (Western blot) in P. aeruginosa. MBX1641 $25 \mu \mathrm{M}$ (ChemBridge) is a T3SS inhibitor that was used as a positive control. (a) Representative image of two independent tests of seven extracts that showed the best anti-pathogenic activity in vivo and that of R. crispus which stimulated death of the animals. (b) Dose-response effect in reducing effector secretion by D. americana and H. sabdariffa extracts. Band intensity is quantified in (c); bands represent the average of three independent tests (Kruskal-Wallis, $p \leq 0.05$, and Student-Newman-Keuls test, $\alpha \leq 0.05 *$ ). The maximum concentration used was $200 \mu \mathrm{g} / \mathrm{mL}$ because higher concentrations presented solubility problems in the assay.

The $\Delta p s c C$ strain did not secrete ExoU, while the commercial inhibitor MBX-1641 $(25 \mu \mathrm{M})$ used as a positive control completely inhibited it in the PA14WT strain (Figure 4a). Furthermore, in $\Delta l a s R / \Delta r h l R$, ExoU secretion remains active (Figure S5). Additionally, five of the seven extracts (71\%) at $100 \mu \mathrm{g} / \mathrm{mL}$ reduced ExoU secretion (Figure 4a) compared to $J$. procumbens, P. peltilimba, and R. crispus (Figure 4a, Table 2). The extracts of D. americana and $H$. sabdariffa that showed the best anti-pathogenic activity (Table 2, Figure 1) were the most efficient in reducing ExoU secretion in a dose-response manner (Figure 4b,c).

\subsubsection{Total Phenolic and Terpenoid Content}

We analyzed the total content in seven plant extracts with the best anti-pathogenic activity (Table 1). In all the extracts, high flavonoid content was identified in the range of 64.35-85.00 mg quercetin equivalent/g of extract and terpenoids with 269.56-550.23 mg ursolic acid equivalent/g of extract (Table S3). The concentration of terpenoids in D. americana is similar to that of T. lucida, P. coccineus, and L. mexicana, although its flavonoid content, like that of H. sabdariffa, is lower than that of P. peltilimba $(p<0.05)$ (Table S3). Finally, for the case of the flavonoid HPLC profile of $D$. americana, it was possible to identify two peaks of greater intensity with UV spectra of the flavone type $\left(\lambda_{\max } 269 / 335 \mathrm{~nm}\right.$ and 270/337 nm) (Figure S6).

\subsection{Role of QS and T3SS in the Pathogenicity of C. violaceum}

The abscess/necrosis model ( $n=3$ mice) was implemented with $C$. violaceum to investigate its potential in the preclinical evaluation of anti-virulence substances. Additionally, to analyze the participation of T3SS in pathogenicity, the mutant strain $\Delta e s c U$ was constructed. Likewise, 12 plant were selected, and their anti-pathogenic capacity was evaluated.

The intramuscular inoculation of $10^{9} \mathrm{CFU}$ of the $31532 \mathrm{WT}$ strain allowed establishment of the bacteria in the inoculation area, and generated abscesses at $24 \mathrm{~h}$ and necrosis at $48 \mathrm{~h}$ but did not cause death of the animals. Similarly, plant extracts at $500 \mu \mathrm{g} / \mathrm{mL}$ did not affect strain viability (Figure S7) nor did they reduce pathogenicity of the bacteria (Table S4). For the case of the mutant strains, no significant differences were recorded in formation of abscesses and necrotic tissue (Table S4). 
We determined the effect of mutations on the production of violacein and some virulence factors. CviI synthase interruption did not alter swarming but reduced proteolytic activity $(35 \%)$, biofilm formation $(77.9 \%)$, and violacein production $(95 \%)$, as well as hemolytic and chitinolytic activity (Table 3). In contrast, in $\triangle e s c U$ the production of these phenotypes was not significantly modified (Table 3, Figure S8).

Table 3. Effect on the production of violacein and virulence factors in QS and T3SS mutant strains of C. violaceum.

\begin{tabular}{cccc}
\hline Phenotype & $31532 \mathbf{W T}$ & $\Delta$ cviI (CVO26) & $\Delta$ escU \\
\hline Violacein & $100 \pm 22.5^{\mathrm{a}}$ & $4.7 \pm 1.1^{\mathrm{b}}$ & $77.7 \pm 30.6^{\mathrm{a}}$ \\
\hline Chitinolytic activity & $100 \pm 2.4^{\mathrm{a}}$ & $0 \pm 0^{\mathrm{b}}$ & $101.6 \pm 3.4^{\mathrm{a}}$ \\
\hline Biofilm formation & $100 \pm 38^{\mathrm{a}}$ & $22.1 \pm 3.4^{\mathrm{b}}$ & $135 \pm 53.7^{\mathrm{a}}$ \\
\hline Proteolytic activity & $100 \pm 1^{\mathrm{a}}$ & $65 \pm 1^{\mathrm{b}}$ & $99.4 \pm 1.2^{\mathrm{a}}$ \\
\hline Hemolytic activity & $100 \pm 2.6^{\mathrm{a}}$ & $0 \pm 0^{\mathrm{b}}$ & $99.5 \pm 2.0^{\mathrm{a}}$ \\
\hline Swarming & $100 \pm 2.5^{\mathrm{a}}$ & $99.6 \pm 4.1^{\mathrm{a}}$ & $100 \pm 1.9^{\mathrm{a}}$
\end{tabular}

\pm S.E., one-way ANOVA and Tukey comparative test. Means without a common letter significantly differ, $p<0.05$.

We subsequently evaluated the effect of the strains on survival in a sepsis model in mice [46]. In the Kaplan-Meier curve, it was observed that the 31532 WT induced death of $50 \%$ of the animals $72 \mathrm{~h}$ after inoculation, and the trend was maintained up to $92 \mathrm{~h}$, when the assay ended (Figure 5). This effect was counteracted when T3SS was blocked since $100 \%$ of the group inoculated with $\Delta e s c U$ survived $(p=0.001)$ (Figure 6). However, when CviI synthase was blocked $(\Delta c v i I)$, there was a $25 \%$ increase in mortality relative to 31532 WT $(p \geq 0.05)$ and $75 \%$ with $\triangle e s c U(p<0.0001)$ (Figure 5). In addition, analysis showed that median survival was higher with 31532 WT $(72 \mathrm{~h})$ than with $\Delta c v i I(20 \mathrm{~h})$.

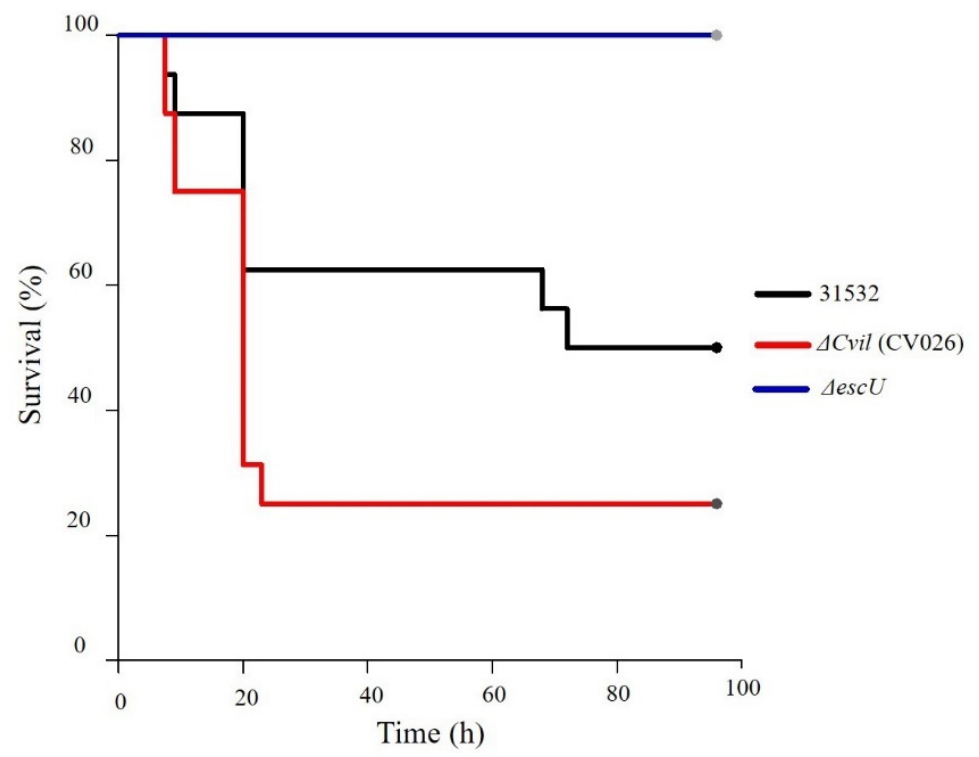

Figure 5. Survival of mice infected with C. violaceum in the sepsis model. Animals were injected intraperitoneally with $3 \times 10^{9} \mathrm{CFU} / 0.2 \mathrm{~mL}$ of each of the strains. The data are representative of two independent experiments with groups of eight mice. The Kaplan-Meier curve was performed with the GraphPad Prisma 6 program (95\% confidence interval) and the data analysis in the SPSS 22.0 program. 


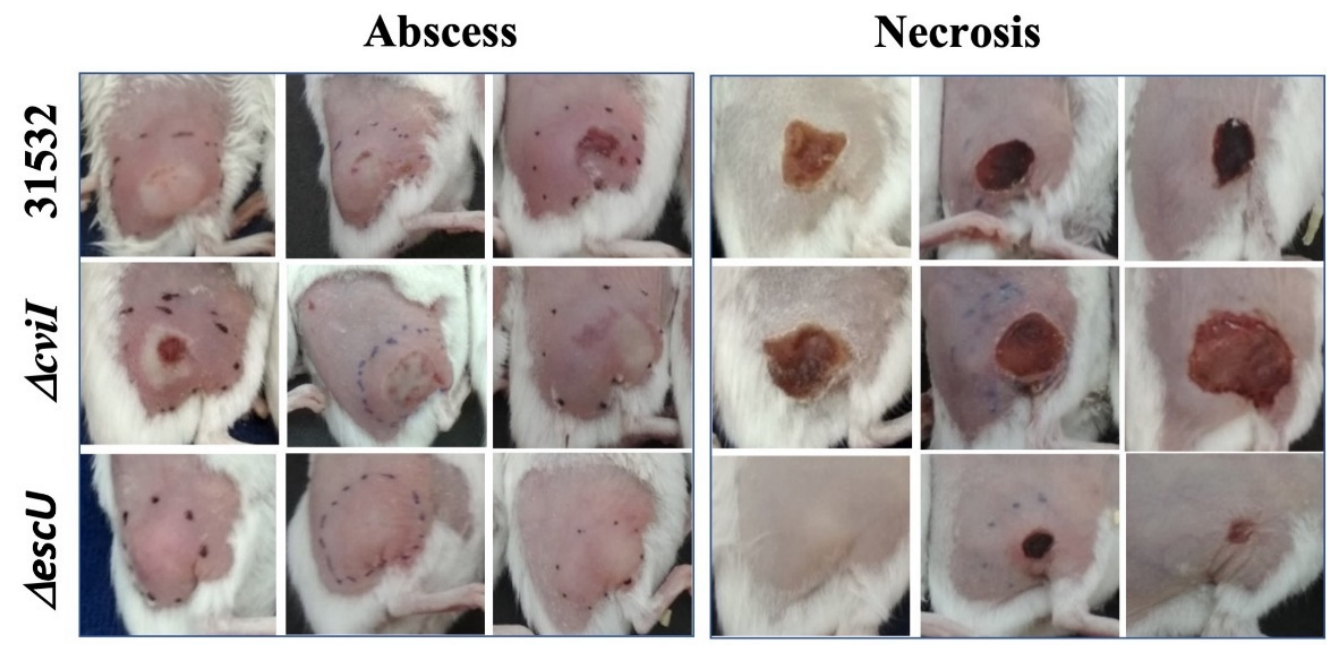

Figure 6. Representative images of abscesses ( $24 \mathrm{~h})$ and necrosis $(96 \mathrm{~h})$ caused by strains of C. violaceum in mice. The animals were injected in the subcutaneous zone with $1.5 \times 10^{9} \mathrm{CFU} / 0.06 \mathrm{~mL}$ of the different strains.

A similar effect was recorded in the abscess/necrosis model using groups of five animals. The $31532 \mathrm{WT}$ strain induced formation of $32.5 \mathrm{~mm}^{2}$ necrotic tissue and establishment of the bacteria in the inoculation area with $\log _{10} 5.2 \mathrm{CFU} / \mathrm{g}$. In contrast, $\triangle e s c U$ induced a smaller abscess area with $102.9 \mathrm{~mm}^{2}(\alpha \leq 0.05)$ and necrosis with $3.12 \mathrm{~mm}^{2}(\alpha \leq 0.05)$, as well as lower establishment in the inoculation area with $\log _{10} 1.8 \mathrm{CFU} / \mathrm{g}(\alpha \leq 0.05)$ (Table 4 and Figure 5). However, $\Delta c v i I$ induced a larger necrotic area of $40.6 \mathrm{~mm}^{2}(\alpha \leq 0.05)$ and establishment of $\log _{10} 6.2 \mathrm{CFU} / \mathrm{g}(\alpha \leq 0.05)$ (Table 4 and Figure 5). It should be noted that there was no systemic dissemination or death of the animals in any of the groups.

Table 4. Role of QS and T3SS of C. violaceum in pathogenicity in abscess/necrosis model.

\begin{tabular}{|c|c|c|c|}
\hline Strain & $\begin{array}{l}\text { Abscess Area }\left(\mathrm{mm}^{2}\right. \\
\text { Mean } \pm \text { S.E. })\end{array}$ & $\begin{array}{l}\text { Necrotic Area }\left(\mathrm{mm}^{2},\right. \\
\text { Mean } \pm \text { S.E. })\end{array}$ & $\begin{array}{c}\text { Bacterial Load in the Inoculation } \\
\text { Area }\left(\log _{10} \text { CFU/g) }\right.\end{array}$ \\
\hline $31532 \mathrm{WT}$ & $145.03 \pm 5.06^{\mathrm{a}}$ & $32.54 \pm 4.03^{\mathrm{a}}$ & $5.3 \pm 0.70^{\mathrm{a}}$ \\
\hline$\Delta c v i I(C V 026)$ & $144.61 \pm 8.7^{\mathrm{a}}$ & $40.69 \pm 5.07^{\mathrm{a}}$ & $6.26 \pm 0.47^{a}$ \\
\hline$\Delta e s c U$ & $103 \pm 6.2^{b}$ & $3.12 \pm 1.38^{b}$ & $1.83 \pm 0.69^{b}$ \\
\hline
\end{tabular}

The abscess area was determined at $24 \mathrm{~h}$ and the necrotic area at $96 \mathrm{~h}$. On the fourth day post-infection, the injured tissue and the liver were obtained to determine the number of CFU/g. The experiment was carried out three times with five mice per group. One-way ANOVA and Tukey comparative test. Means without a common letter significantly differ, $p<0.05$.

\section{Discussion}

The anti-virulence properties (mainly anti-QS) of substances of plant origin constitute a relatively new and rapidly developing field of research, which has positioned plant extracts as one of the top natural products with this activity [6,7]. In P. aeruginosa, pyocyanin and swarming are phenotypes commonly evaluated in this class of studies [17-19,27]. The first is a redox-active pigment that induces pro-inflammatory and oxidative effects that damage host cells [59], while swarming is a type of collective motility on semisolid surfaces that occurs as an adaptive response to microenvironmental changes [60].

With the abscess/necrosis model, we were able to determine the anti-pathogenic activity at the preclinical level of 23 edible and medicinal plant species (Table S1) on $P$. aeruginosa, but of the two variables evaluated in vitro, only swarming inhibition was correlated with the variables in vivo (Figure 3 ). The $H$. sabdariffa extract stands out: it did not inhibit pyocyanin production but reduced pathogenicity of the bacteria in the animal model (similar to $\triangle l a s R / \Delta r h l R$ ) and secretion of ExoU (Figure 5). Additionally, a group of four extracts was identified (R. crispus, I. dumosa, A. glandulosum-L/F, and A. ludoviciana) 
that reduced swarming and pyocyanin production (Figure 2) but increased animal mortality $100 \%$ (Table 2). It should be noted that the increase in mortality was not due to the possible toxicity of the extracts since their administration without bacteria did not cause death of the animals (Figure S9). These results indicate substantial differences between the anti-virulence activity of plant extracts recorded in vitro and their anti-pathogenic effect in the murine model. They also suggest that other elements or mechanisms of the host are involved in the regulation of virulence and are not present in in vitro assays. In this regard, some published studies have shown that QS systems can be modulated by host factors such as the microbiota, neurotransmitters, and stress hormones [61]. It was reported that norepinephrine interferes in QS regulation, favoring enteropathogenic Escherichia coli infection [62], while dynorphin A participates in activating the PQS system by potentiating P. aeruginosa virulence [63].

Additionally, environmental factors such as $\mathrm{pH}$, temperature, and nutrient availability can influence QS modulation and virulence [64]. Two-component systems (TCSs) are one of the primary mechanisms used by bacteria to detect multiple environmental signals and generate an optimal response [65]. In P. aeruginosa, more than 50\% of its TCSs are involved in virulence control or virulence-related behaviors [26].

As mentioned, ExoU is the most toxic effector secreted by the T3SS and an important anti-virulence target [66]. ExoU is a phospholipase that causes rapid cell lysis and necrosis in epithelial cells, but its activation requires host cofactors such as ubiquitin or ubiquitinated proteins [67]. This phospholipase generates an enriched environment of saturated fatty acids in the sputum of patients with cystic fibrosis [68]. However, it was reported that myristic acid reduces the secretion of ExoU in vitro (and other virulence factors regulated by QS) and in the abscess/necrosis model stimulates pathogenicity. Thus, it is suggested that the in vivo function of this saturated fatty acid is to act as an environmental signal molecule for the activation of virulence [69].

Most of the screenings of substances of plant origin have focused on demonstrating the inhibition of QS as the primary anti-virulence mechanism. However, in this research, we found that five of the seven extracts with the highest anti-pathogenic activity also reduce ExoU secretion (Figure 4). Thus, it is feasible that inhibition of multiple targets by different components of the extracts is what determines their anti-pathogenic capacity in the murine model. In this regard, it was reported that various derivatives of phenolic compounds control ExoS expression via the interference of a TCS called GacS-GacA [25]. Additionally, in a global analysis based on omics, it was found that citral (essential oil) acts through several mechanisms to reduce virulence (QS-regulated factors, type II and type IV secretion systems) of A. baumannii [28].

Thus, previous evaluation in the abscess/necrosis model helped to better identify plant extracts with anti-virulence activity against $P$. aeruginosa. We propose that it can be used in plant screening as a preliminary approach to in vitro studies. With this strategy, we identified two plant species with anti-pathogenic properties: D. americana and $H$. sabdariffa. In D. americana there are no studies on its bactericidal or anti-virulence properties. However, extracts from leaves of $D$. robinioides and $D$. carthagenensis are reported to be effective against enterobacteria and Giardia lamblia [70,71] due to the presence of diphysidione and vitexin [72]. In the case of vitexin, sub-inhibitory concentrations have been reported to reduce biofilm formation, swarming, and pyocyanin in P. aeruginosa. Furthermore, the molecular coupling analysis showed a strong binding affinity of this molecule with the LuxR, LasA, and LasI proteins [73]. In this study, we identified the presence of two major flavones in the extract of $D$. americana, so the anti-virulence activity of the extract may be related to the presence of vitexin (Figure S6). In $H$. sabdariffa, the antimicrobial properties of its calyces have been widely documented [74]. However, our research group recently identified hibiscus acid as one of the compounds responsible for anti-virulence activity since it reduced pathogenicity in the abscess/necrosis model [19].

On the other hand, C. violaceum is another widely used biosensor in identifying the anti-QS activity of plant extracts and phytochemicals at the in vitro level [75-77]. The abscess/necrosis 
model was implemented with this bacterium. Although the infection was achieved in small groups of mice $(n=3)$, no significant differences in the reduction of pathogenicity were observed between $\Delta c v i I$ (Cv026) mutant strains and the plant extracts (Table S4). In this regard, it has been shown that QS mutant strains of P. aeruginosa and Staphylococcus aureus have notably lower virulence and dispersion and cause lower mortality than the wild strain in various murine models [3,9-11]. Additionally, similar results have been obtained with the administration of phytochemicals that inhibit QS [15,19,49-51,73]. However, in the case of C. violaceum, the participation of the Cvil/CviR system in pathogenicity in murine models had not yet been analyzed.

Infection with $C$. violaceum in animals is considered rare, and in humans, only in a few cases, the bacterium establishes and causes fatal septicemia [41]. Additionally, CviI/CviR has been reported to regulate various virulence factors [42-44]. The CviI enzyme synthesizes the autoinducer C6-acyl-homoserine lactone, and cviR encodes a cytoplasmic transcription factor called CviR. When the autoinducer concentration increases in the medium, it forms a protein-ligand complex with CviR in the cytoplasm and activates the transcription of the vioABCDE operon to produce violacein [42]. The CV026 ( $\triangle c v i I)$ strain is a widely used biosensor since it does not synthesize C6-acyl-homoserine lactone but expresses the vio $A B C D$ reporter gene if added exogenously to the medium because CviR remains active [78].

Additionally, C. violaceum has genes associated with two T3SSs located on different islands of pathogenicity called Cpi-1/-1a and Cpi-2, but only the first is necessary to generate liver damage and induce death in a mouse model of sepsis [46]. In this manner, in the construction of the $\Delta e s c U$ mutant strain, the escU gene of Cpi-1/-1a was deleted. This codes for a component of the export apparatus for the secretion of effector $\mathrm{CipB}$, which induces the formation of pores in animal cells [46]. When analyzing the effect of these mutations, we corroborated that in $\Delta c v i I$, various virulence factors are attenuated or not produced, while in $\Delta e s c U$, they remain active (Table 3).

In the sepsis model, only $\Delta e s c U$ did not cause death of the animals (Figure 5), which corroborates that T3SS is a virulence determinant in this model [46]. However, contrary to expectations, $\Delta c v i I$ increased mortality in the sepsis model relative to the $31532 \mathrm{WT}$ strain (Figure 5). It is important to note that the growth rate and the degradation pattern of sugars were the same in all strains (Figure S10a,b).

Intraperitoneal inoculation of the bacteria might have been limiting CviI/CviR involvement. We consider that the abscess/necrosis model (subcutaneous inoculation) was more like the way C. violaceum infects through skin wounds [41]. However, we recorded a similar effect of $\Delta c v i I$, which was better established and generated more significant necrosis than 31532 WT (Table 4, Figure 6).

Of the few in vivo studies with $C$. violaceum, it was reported that the $C$. elegans model inoculated with $\Delta c v i$ i delayed nematode death by an average of 12 days, while exogenous addition of C6-acyl-homoserine lactone restored pathogenicity, and animals died within $4 \mathrm{~h}$ [79]. Nevertheless, one explanation for reducing $\Delta$ cviI pathogenicity in the C. elegans model may be related to the nematicide activity of violacein [80].

On the other hand, the importance of the different virulence factors may lie in the ecological niche in which the bacteria develop. The main niche of C. violaceum is in swampy soils, where the production of violacein and other phenotypes regulated by QS allow it to compete for space and resources with other microorganisms [45], while according to our results in animal models, they are not determinants in establishment and damage.

However, T3SS is a virulence determinant with the ability to cause harm and death. In this regard, it has been shown that in other bacterial species, negative regulation can occur between the QS and T3SS systems [81]. In this study, we could not assess whether the $\Delta c v i I$ strain had increased effector production caused by possible down-regulation with T3SS. Additionally, in bacterial isolates from lesions, contaminating colonies were commonly present, and it is thus possible that exogenous autoinducers activated the QS of 
$\Delta c v i I$. However, although our results indicate that cvil is not a pathogenicity determinant in murine models, studying this phenomenon in greater depth is necessary.

In conclusion, the abscess/necrosis model makes it possible to evaluate the antivirulence capacity of plant extracts at the preclinical level on P. aeruginosa. Contrary to expectations, the results suggest that the elimination of cviI in the QS system may favor the pathogenicity of $C$. violaceum in murine models. Finally, studies are needed to understand the host factors that drive global virulence to develop more effective antivirulence therapies.

Supplementary Materials: The following are available online at https:/ /www.mdpi.com/article/10 .3390 /microorganisms9122424/s1. Figure S1. Effect of plant extracts on the viability of P. aeruginosa PA14 WT. The viability of the bacteria was determined by plate count. Blue dots indicate the extracts that reduced pathogenicity in the animal model and red dots those that stimulated it. Figure S2. Images of the experiment in Table 2. Abscess formation at $24 \mathrm{~h}$ (A) and necrosis at $48 \mathrm{~h}$ (B). Survival was measured up to $96 \mathrm{~h}$ (C). Kaplan-Meier survival curve (D). The animals were sacrificed to quantify the presence of the bacteria in the tissues. The experiment was conducted once with groups of three animals per treatment, except the control groups with PA14 WT, which were two independent tests with three and four animals. Figure S3. A: D. americana; B: H. sabdariffa; C: J. procumbens; D: P. coccineus; E: P. peltilimba; F: R. crispus; and G: I. dumosa. Figure S4. Representative images of the effect of plant extracts (125 and $250 \mu \mathrm{g} / \mathrm{mL}$ ) on P. aeruginosa swarming. C-30, furanone C30 (50 $\mu \mathrm{M})$. Figure S5. ExoU protein secretion (Western blot) in P. aeruginosa mutant strains. Representative image of three independent experiments. Figure S6. HPLC chromatogram showing two peaks corresponding to possible flavones from the dichloromethane extract of D. americana. Figure S7. Effect of dichloromethane extracts on the viability of C. violaceum 31532 WT. Before inoculation in the animals, the bacteria were incubated with the extracts for $20 \mathrm{~min}$ at room temperature. Viability was determined through a standard plate count. Figure S8. Effect on the production of virulence factors in QS and T3SS mutant strains of $C$. violaceum. Figure S9. Images of the areas where the dichloromethane extracts without bacteria (PA14 WT) were administered. Figure S10. A: growth curve of the 313532 WT strain and its derived mutant strains. B: TSI medium for the degradation of sugars. Table S1. Collection site and yield of dichloromethane extracts. Table S2. Strains used in this study $[82,83]$. Table S3. Quantitative determination of flavonoids and terpenoids from anti-pathogenic extracts. Table S4. Effect of plant extracts at sub-inhibitory concentration on the pathogenicity of $C$. violaceum.

Author Contributions: Conceived and designed the project: I.C.-J., M.P.-L., J.L.D.-N., B.G.-P., R.G.-C. and H.Q. Wrote the manuscript with the input of all coauthors: J.L.D.-N., I.C.-J. and M.P.-L.; J.L.D.-N., M.P.-L., N.E. and M.D.-G. performed experiments with the help of N.C.-H., H.C.-L., M.V.-S. and M.B.-H. Critically reviewed the manuscript: B.G.-P., M.M.-V. and R.M.S.-H. All authors contributed to the article and approved the submitted version. All authors have read and agreed to the published version of the manuscript.

Funding: This work was supported by grants from Scientific Development Projects for Solving National Problems/CONACyT Mexico No. 2015-01-402, and federal funding HIM/2018/002 SSA. 1475. J.L.D.N. thanks CONACYT for her doctoral scholarship (735716). I.C.-J. was supported by the CátedrasCONACyT program. R.G.-C. is funded by CONACYT grant CB 2017-2018 number A1-S-8530.

Institutional Review Board Statement: All experiments with mice were carried out following the indications of the Research, Ethics and Biosafety Committees of the Hospital Infantil de MéxicoFederico Gómez (Approval number: HIM2018-002. 21 May 2018).

Informed Consent Statement: Not applicable.

Data Availability Statement: Not applicable.

Acknowledgments: The authors acknowledge Luis Antonio Flores Hernández for advising on multivariate analysis.

Conflicts of Interest: The authors declare that the research was conducted in the absence of any commercial or financial relationship that could be construed as a potential conflict of interest. 


\section{References}

1. Zhou, L.; Slamti, L.; Nielsen-LeRoux, C.; Lereclus, D.; Raymond, B. The social biology of quorum sensing in a naturalistic host pathogen system. Curr. Biol. 2014, 24, 2417-2422. [CrossRef]

2. Troselj, V.; Cao, P.; Wall, D. Cell-cell recognition and social networking in bacteria. Environ Microbiol. 2018, 20, 923-933. [CrossRef]

3. Castillo-Juárez, I.; Maeda, T.; Mandujano-Tinoco, E.A.; Tomás, M.; Pérez-Eretza, B.; García-Contreras, S.J.; Wood, T.K.; GarcíaContreras, R. Role of quorum sensing in bacterial infections. World J. Clin. Cases 2015, 3, 575-598. [CrossRef]

4. Borges, A.; Abreu, A.C.; Dias, C.; Saavedra, M.J.; Borges, F.; Simões, M. New perspectives on the use of phytochemicals as an emergent strategy to control bacterial infections including biofilms. Molecules 2016, 21, 877. [CrossRef] [PubMed]

5. Whiteley, M.; Diggle, S.P.; Greenberg, E.P. Progress in and promise of bacterial quorum sensing research. Nature 2017, 551, 313-320. [CrossRef]

6. Deryabin, D.; Galadzhieva, A.; Kosyan, D.; Duskaev, G. Plant-derived inhibitors of AHL-mediated quorum sensing in bacteria: Modes of action. Int. J. Mol. Sci. 2019, 20, 5588. [CrossRef] [PubMed]

7. Díaz-Nuñez, J.L.; García-Contreras, R.; Castillo-Juárez, I. The new antibacterial properties of the plants: Quo vadis studies of anti-virulence phytochemicals? Front. Microbiol. 2021, 12, 667126. [CrossRef] [PubMed]

8. Papaioannou, E.; Utari, P.D.; Quax, W.J. Choosing an appropriate infection model to study quorum sensing inhibition in Pseudomonas infections. Int. J. Mol. Sci. 2013, 14, 19309-19340. [CrossRef]

9. Tang, H.B.; DiMango, E.; Bryan, R.; Gambello, M.; Iglewski, B.H.; Goldberg, J.B.; Prince, A. Contribution of specific Pseudomonas aeruginosa virulence factors to pathogenesis of pneumonia in a neonatal mouse model of infection. Infect. Immun. 1996, 64, 37-43. [CrossRef]

10. Rumbaugh, K.P.; Griswold, J.A.; Hamood, A.N. Contribution of the regulatory gene lasR to the pathogenesis of Pseudomonas aeruginosa infection of burned mice. J. Burn Care Rehabil. 1999, 20, 42-49. [CrossRef]

11. Rumbaugh, K.P.; Griswold, J.A.; Iglewski, B.H.; Hamood, A.N. Contribution of quorum sensing to the virulence of Pseudomonas aeruginosa in burn wound infections. Infect. Immun. 1999, 67, 5854-5862. [CrossRef]

12. Lesic, B.; Lépine, F.; Déziel, E.; Zhang, J.; Zhang, Q.; Padfield, K.; Castonguay, M.-H.; Milot, S.; Stachel, S.; Tzika, A.A.; et al. Inhibitors of pathogen intercellular signals as selective anti-infective compounds. PLoS Pathog. 2007, 3, 1229-1239. [CrossRef]

13. Christensen, L.D.; Moser, C.; Jensen, P.Ø.; Rasmussen, T.B.; Christophersen, L.; Kjelleberg, S.; Kumar, N.; Høiby, N.; Givskov, M.; Bjarnsholt, T. Impact of Pseudomonas aeruginosa quorum sensing on biofilm persistence in an in vivo intraperitoneal foreign-body infection model. Microbiology 2007, 15, 2312-2320. [CrossRef] [PubMed]

14. Jakobsen, T.H.; van Gennip, M.; Phipps, R.K.; Shanmugham, M.S.; Christensen, L.D.; Alhede, M.; Skindersoe, M.E.; Rasmussen, T.B.; Friedrich, K.; Uthe, F.; et al. Ajoene, a sulfur-rich molecule from garlic, inhibits genes controlled by quorum sensing. Antimicrob. Agents Chemother. 2012, 56, 2314-2325. [CrossRef]

15. Harjai, K.; Kumar, R.; Singh, S. Garlic blocks quorum sensing and attenuates the virulence of Pseudomonas aeruginosa. FEMS Immunol. Med. Microbiol. 2010, 58, 161-168. [CrossRef] [PubMed]

16. Steindler, L.; Venturi, V. Detection of quorum-sensing $N$-acyl homoserine lactone signal molecules by bacterial biosensors. FEMS Microbiol. Lett. 2007, 266, 1-9. [CrossRef]

17. Castillo-Juárez, I.; García-Contreras, R.; Velázquez-Guadarrama, N.; Soto-Hernández, M.; Martínez-Vázquez, M. Anacardic acid from Amphypterygium adstringens inhibits quorum sensing-controlled virulence factors of Chromobacterium violaceum and Pseudomonas aeruginosa. Arch. Med. Res. 2013, 44, 488-494. [CrossRef]

18. Vasavi, H.S.; Arun, A.B.; Rekha, P.D. Anti-quorum sensing activity of Psidium guajava L. flavonoids against Chromobacterium violaceum and Pseudomonas aeruginosa PAO1. Microbiol. Immunol. 2014, 8, 286-293. [CrossRef] [PubMed]

19. Cortes-López, H.; Castro-Rosas, J.; García-Contreras, R.; Rodríguez-Zavala, J.S.; González-Pedrajo, B.; Díaz-Guerrero, M.; Hernández-Morales, J.; Muñoz-Cazares, N.; Soto-Hernández, M.; Ruíz-Posadas, L.D.; et al. Anti-virulence activity of a dietary phytochemical: Hibiscus acid isolated from Hibiscus sabdariffa reduces the virulence of Pseudomonas aeruginosa in a mouse infection model. J. Med. Food. 2021, 24, 1557-7600. [CrossRef]

20. Vikram, A.; Jayaprakasha, G.K.; Jesudhasan, P.R.; Pillai, S.D.; Patil, B.S. Suppression of bacterial cell-cell signaling, biofilm formation and type III secretion system by citrus flavonoids. J. Appl. Microbiol. 2010, 109, 515-527. [CrossRef]

21. Zetterström, E.C.; Hasselgren, J.; Salin, O.; Davis, R.A.; Quinn, R.J.; Sudin, C.; Elofsson, M. The resveratrol tetramer (-)hopeaphenol inhibits type III secretion in the Gram-negative pathogens Yersinia pseudotuberculosis and Pseudomonas aeruginosa. PLoS ONE 2013, 8, e81969. [CrossRef]

22. Li, H.; Zhao, X.; Wang, J.; Dong, Y.; Meng, S.; Li, R.; Niu, X.; Deng, X. Beta-sitosterol interacts with pneumolysin to prevent Streptococcus pneumoniae infection. Sci. Rep. 2015, 5, 17668. [CrossRef]

23. Dell'Aica, I.; Donà, M.; Tonello, F.; Piris, A.; Mock, M.; Montecucco, C.; Garbisa, S. Potent inhibitors of anthrax lethal factor from green tea. EMBO Rep. 2004, 5, 418-422. [CrossRef] [PubMed]

24. Kanojia, R.M.; Murray, W.; Bernstein, J.; Fernandez, J.; Foleno, B.D.; Krause, H.; Lawrence, L.; Webb, G.; Barrette, J.F. 6-Oxa isosteres of anacardic acids as potent inhibitors of bacterial histidine protein kinase (HPK)-mediated two-component regulatory systems. Bioorg. Med. Chem. Lett. 1999, 9, 2947-2952. [CrossRef]

25. Yamazaki, A.; Li, J.; Zeng, Q.; Khokhani, D.; Hutchins, W.C.; Yost, A.C.; Biddle, E.; Toone, E.J.; Chen, X.; Yang, C.-H. Derivatives of plant phenolic compound affect the type III secretion system of Pseudomonas aeruginosa via a GacS-GacA two-component signal transduction system. Antimicrob. Agents. Chemother. 2012, 56, 36-43. 
26. Francis, V.I.; Stevenson, E.C.; Porter, S.L. Two-component systems required for virulence in Pseudomonas aeruginosa. FEMS Microbiol. Lett. 2017, 364, fnx104. [CrossRef]

27. Muñoz-Cazares, N.; García-Contreras, R.; Soto-Hernández, M.; Martínez-Vázquez, M.; Castillo-Juárez, I. Chapter 10: Natural products with quorum quenching independent anti-virulence properties. In Studies in Natural Products Chemistry, 1st ed.; Atta-ur-Rahma, T.I., Ed.; Elsevier Science Publishers: Amsterdam, The Netherlands, 2018; pp. 327-351.

28. Selvaraj, A.; Valliammai, A.; Muthuramalingam, P.; Sethupathy, S.; Subramenium, G.A.; Ramesh, M.; Pandian, S.K. Proteomic and systematic functional profiling unveils citral targeting antibiotic resistance, antioxidant defense, and biofilm-associated two-component systems of Acinetobacter baumannii to encumber biofilm and virulence traits. mSystems 2020, 5, e00986-20. [CrossRef]

29. García-Contreras, R.; Maeda, T.; Wood, T.K. Can resistance against quorum-sensing interference be selected? ISME J. 2016, 10, 4-10. [CrossRef] [PubMed]

30. Pachori, P.; Gothalwal, R.; Gandhi, P. Emergence of antibiotic resistance Pseudomonas aeruginosa in intensive care unit; a critical review. Genes Dis. 2019, 6, 109-119. [CrossRef] [PubMed]

31. Castillo-Juárez, I.; López-Jácome, L.E.; Soberón-Chávez, G.; Tomás, M.; Lee, J.; Castaneda-Tamez, P.; Hernandez-Barragan, I.A.; Cruz-Muniz, M.Y.; Maeda, T.; Wood, T.K.; et al. Exploiting quorum sensing inhibition for the control of Pseudomonas aeruginosa and Acinetobacter baumannii biofilms. Curr. Top. Med. Chem. 2017, 17, 1915-1927. [CrossRef]

32. Lee, J.; Zhang, L. The hierarchy quorum sensing network in Pseudomonas aeruginosa. Protein Cell 2015, 6, 26-41. [CrossRef]

33. Ryan, R.P.; Fouhy, Y.; Garcia, B.F.; Watt, S.A.; Niehaus, K.; Yang, L.; Tolker-Nielsen, T.; Dow, J.M. Interspecies signaling via the Stenotrophomonas maltophilia diffusible signal factor influences biofilm formation and polymyxin tolerance in Pseudomonas aeruginosa. Mol. Microbiol. 2008, 68, 75-86. [CrossRef]

34. Ryan, R.P.; An, S.-q.; Allan, J.H.; McCarthy, Y.; Dow, J.M. The DSF family of cell-cell signals: An expanding class of bacterial virulence regulators. PLoS Pathog. 2015, 11, e1004986. [CrossRef]

35. Zhou, L.; Zhang, L.-H.; Cámara, M.; He, Y.-W. The DSF family of quorum sensing signals: Diversity, biosynthesis, and turnover. Trends Microbiol. 2017, 25, 293-303. [CrossRef]

36. Amari, D.T.; Marques, C.N.H.; Davies, D.G. The putative enoylcoenzyme a hydratase DspI is required for production of the Pseudomonas aeruginosa biofilm dispersion autoinducer cis-2-decenoic acid. J. Bacteriol. 2013, 195, 4600-4610. [CrossRef]

37. Liu, L.; Li, T.; Cheng, X.J.; Peng, C.T.; Li, C.C.; He, L.H.; Ju, S.M.; Wang, N.Y.; Ye, T.H.; Lian, M.; et al. Structural and functional studies on Pseudomonas aeruginosa DspI: Implications for its role in DSF biosynthesis. Sci. Rep. 2018, 8, 3928. [CrossRef] [PubMed]

38. Jiang, F.; Waterfield, N.R.; Yang, J.; Yang, G.; Jin, Q. A Pseudomonas aeruginosa type VI secretion phospholipase D effector targets both prokaryotic and eukaryotic cells. Cell Host Microbe 2014, 15, 600-610. [CrossRef] [PubMed]

39. Sato, H.; Frank, D.W. ExoU is a potent intracellular phospholipase. Mol. Microbiol. 2004, 53, 1279-1290. [CrossRef] [PubMed]

40. Foulkes, D.M.; McLean, K.; Haneef, A.S.; Fernig, D.G.; Winstanley, C.; Berry, N.; Kaye, S.B. Pseudomonas aeruginosa toxin ExoU as a therapeutic target in the treatment of bacterial infections. Microorganisms 2019, 7, 707. [CrossRef]

41. Batista, J.H.; da Silva Neto, J.F. Chromobacterium violaceum pathogenicity: Updates and insights from genome sequencing of novel Chromobacterium species. Front Microbiol. 2017, 10, 2213. [CrossRef] [PubMed]

42. Stauff, D.L.; Bassler, B.L. Quorum sensing in Chromobacterium violaceum: DNA recognition and gene regulation by the CviR receptor. J. Bacteriol. 2011, 193, 3871-3878. [CrossRef]

43. de Oca-Mejía, M.M.; Castillo-Juárez, I.; Martínez-Vázquez, M.; Soto-Hernández, M.; García-Contreras, R. Influence of quorum sensing in multiple phenotypes of the bacterial pathogen Chromobacterium violaceum. Pathog. Dis. 2015, 73, 1-4. [CrossRef]

44. Chernin, L.S.; Winson, M.K.; Thompson, J.M.; Haran, S.; Bycroft, B.W.; Chet, I.; Williams, P.; Stewart, G.S.A.B. Chitinolytic activity in Chromobacterium violaceum: Substrate analysis and regulation by quorum sensing. J. Bacteriol. 1998, 180, 4435-4441. [CrossRef] [PubMed]

45. Mion, S.; Carriot, N.; Lopez, J.; Plener, L.; Ortalo-Magné, A.; Chabrière, E.; Culioli, G.; Daudé, D. Disrupting quorum sensing alters social interactions in Chromobacterium violaceum. NPJ Biofilms Microbiomes 2021, 7, 40. [CrossRef]

46. Miki, T.; Iguchi, M.; Akiba, K.; Hosono, M.; Sobue, T.; Danbara, H.; Okada, N. Chromobacterium pathogenicity island 1 type III secretion system is a major virulence determinant for Chromobacterium violaceum-induced cell death in hepatocytes. Mol. Microbiol. 2010, 77, 855-872. [CrossRef] [PubMed]

47. Pletzer, D.; Mansour, S.C.; Wuerth, K.; Rahanjam, N.; Hancock, R.E. New mouse model for chronic infections by Gram-negative bacteria enabling the study of anti-infective efficacy and host-microbe interactions. mBio 2017, 8, e00140-17. [CrossRef]

48. Berube, B.J.; Murphy, K.R.; Torhan, M.C.; Bowlin, N.O.; Williams, J.D.; Bowlin, T.L.; Moir, D.T.; Hauser, A.R. Impact of type III secretion effectors and of phenoxyacetamide inhibitors of type III secretion on abscess formation in a mouse model of Pseudomonas aeruginosa infection. Antimicrob. Agents Chemother. 2017, 6, e01202-17. [CrossRef] [PubMed]

49. Quave, C.L.; Lyles, J.T.; Kavanaugh, J.S.; Nelson, K.; Parlet, C.P.; Crosby, H.A.; Heilmann, K.P.; Horswill, A.R. Castanea sativa (European chestnut) leaf extracts rich in ursene and oleanene derivatives block Staphylococcus aureus virulence and pathogenesis without detectable resistance. PLOS ONE 2015, 10, e0136486.

50. Muhs, A.; Lyles, J.T.; Parlet, C.P.; Nelson, K.; Kavanaugh, J.S.; Horswill, A.R.; Quave, C.L. Virulence inhibitors from Brazilian peppertree block quorum sensing and abate dermonecrosis in skin infection models. Sci. Rep. 2017, 7, 42275. [CrossRef]

51. Tang, H.; Porras, G.; Brown, M.M.; Chassagne, F.; Lyles, J.T.; Bacsa, J.; Horswill, A.R.; Quave, C.L. Triterpenoid acids isolated from Schinus terebinthifolia fruits reduce Staphylococcus aureus virulence and abate dermonecrosis. Sci Rep. 2020, 10, 8046. [CrossRef] 
52. Chang, C.-C.; Yang, M.-H.; Wen, H.-M.; Chern, J.-C. Estimation of total flavonoid content in propolis by two complementary colorimetric methods. J. Food Drug Anal. 2002, 10, 178-182.

53. Fan, J.; He, C. Simultaneous quantification of three major bioactive triterpene acids in the leaves of diospyros kaki by highperformance liquid chromatography method. J. Pharm. Biomed. Anal. 2006, 41, 950-956. [CrossRef] [PubMed]

54. Kollaran, A.M.; Joge, S.; Kotian, H.S.; Badal, D.; Prakash, D.; Mishra, A.; Varma, M.; Singh, V. Context-specific requirement of forty-four two-component loci in Pseudomonas aeruginosa swarming. iScience 2019, 13, 305-317. [CrossRef] [PubMed]

55. Muñoz-Cazares, N.; García-Contreras, R.; Pérez-López, M.; Castillo- Juárez, I. Phenolic compounds with anti-virulence properties. In Phenolic Compounds-Biological Activity, 1st ed.; Soto-Hernández, M., Tenango, M.P., García-Mateos, R., Eds.; IntechOpen: London, UK, 2017; pp. 139-167.

56. Pineda-Castellanos, M.L.; Rodríguez-Segura, Z.; Villalobos, F.J.; Hernández, L.; Lina, L.; Núñez-Valdez, M.E. Pathogenicity of isolates of Serratia marcescens towards larvae of the scarab Phyllophaga blanchardi (Coleoptera). Pathogens 2015, 4, 210-228. [CrossRef] [PubMed]

57. Souza, C.P.; Burbano-Rosero, E.M.; Almeida, B.C.; Martins, G.G.; Albertini, L.S.; Rivera, I.N.G. Culture medium for isolating chitinolytic bacteria from seawater and plankton. World J. Microbiol. Biotechnol. 2009, 25, 2079-2082. [CrossRef]

58. Liu, Z.; Wang, W.; Zhu, Y.; Gong, Q.; Yu, W.; Lu, X. Antibiotics at subinhibitory concentrations improve the quorum sensing behavior of Chromobacterium violaceum. FEMS Microbiol. Lett. 2013, 341, 37-44. [CrossRef]

59. Lau, G.W.; Hassett, D.J.; Ran, H.; Kong, F. The role of pyocyanin in Pseudomonas aeruginosa infection. Trends Mol. Med. 2004, 10, 599-606. [CrossRef]

60. Chrzanowski, L.; Ławniczak, L.; Czaczyk, K. Why do microorganisms produce rhamnolipids? World J. Microbiol. Biotechnol. 2012, 28, 401-419. [CrossRef]

61. Turkina, M.V.; Vikström, E. Bacteria-host crosstalk: Sensing of the quorum in the context of Pseudomonas aeruginosa infections. J. Innate Immun. 2019, 11, 263-279. [CrossRef] [PubMed]

62. Bansal, T.; Englert, D.; Lee, J.; Hegde, M.; Wood, T.K.; Jayaraman, A. Differential effects of epinephrine, norepinephrine, and indole on Escherichia coli O157:H7 chemotaxis, colonization, and gene expression. Infect. Immun. 2007, 75, 4597-4607. [CrossRef] [PubMed]

63. Zaborina, O.; Lepine, F.; Xiao, G.; Valuckaite, V.; Chen, Y.; Li, T.; Ciancio, M.; Zaborin, A.; Petroff, E.; Turner, J.R.; et al. Dynorphin activates quorum sensing quinolone signaling in Pseudomonas aeruginosa. PLoS Pathog. 2007, 3, e35.

64. Bettenworth, V.; Steinfeld, B.; Duin, H.; Petersen, K.; Streit, W.R.; Bischofs, I.B.; Becker, A. Phenotypic heterogeneity in bacterial quorum sensing systems. J. Mol. Boil. 2019, 431, 4530-4546. [CrossRef]

65. Zschiedrich, C.P.; Keidel, V.; Szurmant, H. Molecular mechanisms of two-component signal transduction. J. Mol. Biol. 2016, 428, 3752-3775. [CrossRef] [PubMed]

66. Anantharajah, A.; Mingeot-Leclercq, M.P.; Van Bambeke, F. Targeting the type three secretion system in Pseudomonas aeruginosa. Trends Pharmacol. Sci. 2016, 37, 734-749. [CrossRef] [PubMed]

67. Tyson, G.H.; Hauser, A.R. Phosphatidylinositol 4,5-bisphosphate is a novel coactivator of the Pseudomonas aeruginosa cytotoxin ExoU. Infect. Immun. 2013, 81, 2873-2881. [CrossRef]

68. Son, M.S.; Matthews, W.J.; Kang, Y.; Nguyen, D.T.; Hoang, T.T. In vivo evidence of Pseudomonas aeruginosa nutrient acquisition and pathogenesis in the lungs of cystic. Infect. Immun. 2007, 75, 5313-5324. [CrossRef]

69. Juárez-Rodríguez, M.M.; Cortes-López, H.; García-Contreras, R.; González- Pedrajo, B.; Díaz-Guerrero, M.; Martínez-Vázquez, M.; Rivera-Chávez, J.A.; Soto-Hernández, R.M.; Castillo-Juárez, I. Dodecanoic and tetradecanoic acids with in vitro anti-virulence properties increase the pathogenicity of Pseudomonas aeruginosa in a murine cutaneous infection model. Front Cell Infect. Microbiol. 2021, 10, 597517. [CrossRef]

70. Cáceres, A.; Fletes, L.; Aguilar, L.; Ramírez, O.; Figueroa, L.; Taracena, A.M.; Samayoa, B. Plants used in Guatemala for the treatment of gastrointestinal disorders. Confirmation of activity against enterobacteria of 16 plants. J. ethnopharmacol. 1993, 38, 31-38. [CrossRef]

71. Peraza-Sánchez, S.R.; Poot-Kantún, S.; Torres-Tapia, L.W.; May-Pat, F.; Simá-Polanco, P.; Cedillo-Rivera, R. Screening of native plants from Yucatan for anti-Giardia lamblia activity. Pharm. Biol. 2005, 43, 594-598. [CrossRef]

72. Torres-Tapia, L.W.; Sosa-Espinosa, T.; Peraza-Sánchez, S.R. Isolation of a p-hydroxyphenyl anhydride from the leaves of Diphysa carthagenensisw. Nat. Prod. Res. 2013, 27, 286-289. [CrossRef]

73. Das, M.C.; Sandhu, P.; Gupta, P.; Rudrapaul, P.; De, U.C.; Tribedi, P.; Akhter, Y.; Bhattacharjee, S. Attenuation of Pseudomonas aeruginosa biofilm formation by vitexin: A combinatorial study with azithromycin and gentamicin. Sci. Rep. 2016, 6, 23347. [CrossRef]

74. Izquierdo-Vega, J.A.; Arteaga-Badillo, D.A.; Sánchez-Gutiérrez, M.; Morales-González, J.A.; Vargas-Mendoza, N.; Gómez-Aldapa, C.A.; Castro-Rosas, J.; Delgado-Olivares, L.; Madrigal-Bujaidar, E.; Madrigal-Santillán, E. Organic acids from roselle (Hibiscus sabdariffa L.)-A brief review of its pharmacological effects. Biomedicines 2020, 8, 100. [CrossRef] [PubMed]

75. Vattem, D.A.; Mihalik, K.; Crixell, S.H.; McLean, R.J. Dietary phytochemicals as quorum sensing inhibitors. Fitoterapia 2007, 78, 302-310. [CrossRef]

76. Al-Haidari, R.A.; Shaaban, M.I.; Ibrahim, S.R.M.; Mohamed, G.A. Anti-quorum sensing activity of some medicinal plants. Afr. J. Tradit. Complement. Altern. Med. 2016, 13, 67-71. 
77. Cosa, S.; Chaudhary, S.K.; Chen, W.; Combrinck, S.; Viljoen, A. Exploring common culinary herbs and spices as potential anti-quorum sensing agents. Nutrients 2019, 11, 739. [CrossRef] [PubMed]

78. McClean, K.H.; Winson, M.K.; Fish, L.; Taylor, A.; Chhabra, S.R.; Camara, M.; Daykin, M.; Lamb, J.H.; Swift, S.; Bycroft, B.W.; et al Quorum sensing and Chromobacterium violaceum: Exploitation of violacein production and inhibition for the detection of $\mathrm{N}$-acyl homoserine lactones. Microbiology 1997, 143, 3703-3711. [CrossRef] [PubMed]

79. Swem, L.R.; Swem, D.L.; O'Loughlin, C.T.; Gatmaitan, R.; Zhao, B.; Ulrich, S.M.; Bassler, B.L. A quorum-sensing antagonist targets both membrane bound and cytoplasmic receptors and controls bacterial pathogenicity. Mol. Cell 2009, 35, 143-153. [CrossRef]

80. Ballestriero, F.; Daim, M.; Penesyan, A.; Nappi, J.; Schleheck, D.; Bazzicalupo, P.; Schiavi, E.D.; Egan, S. Antinematode activity of violacein and the role of the insulin/IGF-1 pathway in controlling violacein sensitivity in Caenorhabditis elegans. PLoS ONE 2014, 9, e109201.

81. Pena, R.T.; Blasco, L.; Ambroa, A. Relationship between quorum sensing and secretion systems. Front Microbiol. 2019, 10, 1100. [CrossRef]

82. Liberati, N.T.; Urbach, J.M.; Miyata, S.; Lee, D.G.; Drenkard, E.; Wu, G.; Villanueva, J.; Wei, T.; Ausubel, F.M. An ordered, nonredundant library of Pseudomonas aeruginosa strain PA14 transposon insertion mutants. Proc. Natl. Acad. Sci. USA 2006, 103, 2833-2838. [CrossRef]

83. Dekimpe, V.; Déziel, E. Revisiting the quorum-sensing hierarchy in Pseudomonas aeruginosa: The transcriptional regulator RhlR regulates LasR-specific factors. Microbiology 2009, 55, 712-723. [CrossRef] [PubMed] 